\title{
Öğrenme Halkası Modellerinin Fen Öğretiminde Öğrencilerin Öğrenme Ürünlerine Etkisi: Meta Analiz Çalışması
}

\author{
Hakan Saraç $^{1}$ \\ ${ }^{1}$ Milli Eğitim Müdürlüğü, İstanbul, Türkiye
}

Sorumlu Yazar: Hakan Saraç, hknsrcmv@gmail.com

Makale Türü: Araştırma Makalesi

Kaynak Gösterimi: Saraç, H. (2018). Öğrenme halkası modellerinin fen öğretiminde öğrencilerin öğrenme ürünlerine etkisi: Meta analiz çalışması. Eğitimde Kuram ve Uygulama, 14(3), 250-275. doi:10.17244/eku.305929

\section{The Effect of Learning Cycle Models Usage on Students’ Learning Outcomes at Science: Meta-} Analysis Study

Hakan Saraç $^{1}$

\author{
${ }^{1}$ Directorate of National Education, İstanbul, Turkey
}

Corresponding Author: Hakan Saraç, hknsrcmv@gmail.com

Article Type: Research Article

To Cite This Article: Saraç, H. (2018). Öğrenme halkası modellerinin fen öğretiminde öğrencilerin öğrenme ürünlerine etkisi: Meta analiz çalışması. Eğitimde Kuram ve Uygulama, 14(3), 250-275. doi:10.17244/eku.305929 


\title{
Öğrenme Halkası Modellerinin Fen Öğretiminde Öğrencilerin Öğrenme Ürünlerine Etkisi: Meta Analiz Çalıșması
}

\author{
Hakan Saraç ${ }^{1}$ \\ ${ }^{1}$ Milli Eğitim Müdürlüğ̈̈, İstanbul, Türkiye \\ ORCID: ...
}

\begin{tabular}{l}
\hline Öz \\
\hline Araştırmada, Fen öğretiminde yapılandırmacı yaklaşım öğrenme halkası modeli \\
kullanımının öğrencilerin öğrenme ürünlerine etkisini belirlemek amacıyla meta analiz \\
çalışması yapılmıştır. 2007-2016 yılları arasında yapılmış araştırma problemine uygun, \\
meta analiz çalışmasına dahil edilebilecek istatistiksel verilere sahip doktora ve yüksek \\
lisans tezleri Türkçe ve İngilizce anahtar kelimeler kullanılarak literatür taraması \\
yapılmıştır. Tarama sonucunda, öğrenme halkası modelleri kullanımının öğrencilerin \\
öğrenme ürünlerine etkisine ilişkin toplam 107 lisansüstü tez (50 doktora tezi ve 57 \\
yüksek lisans tezi) meta analize dahil edilmiş ve toplamda 227 etki büyüklüğü değeri elde \\
edilmiştir. Araştırma sonucunda Fen öğretiminde öğrenme halkası modelleri kullanımının \\
öğrencilerde öğrenme ürünlerine etkisinin pozitif yönde olduğu tespit edilmiş ve tespit \\
edilen etki büyüklüğü değeri, rastgele etkiler modeline göre ,862 ile 1,072 güven \\
aralığında, ,967 (\% 95 GA, EB = ,054) olarak bulunmuştur ve bu değer geniş düzeyde bir \\
etkiyi belirtmektedir. Araştırmada elde edilen 227 etki büyüklüğü değerinin 209’’u pozitif, \\
18’i negatiftir. Araştırmada öğrencilerin öğrenme ürünlerine, öğrenme halkası \\
modellerine, araştırmanın tez türüne, araştırmanın yapıldığı Fen alanına ve araştırmaya \\
katılan öğrencilerin öğrenim düzeylerine göre moderatör analizler yapıllmıştır. Yapılan \\
analizler sonucunda, en yüksek etki büyüklüğü değerinin öğrenilen bilgilerin akılda \\
kalıcılığında (EB = 1,521), 4E Modelinde (2,289), yüksek lisans çalışmalarında (EB = \\
1,081), Fen bilimler dersleri alanında (EB = 1,118) ve ilkokul öğrencilerinde (EB = 1,540) \\
olduğu tespit edilmiştir.
\end{tabular}

\begin{tabular}{l} 
Makale Bilgisi \\
\hline Anahtar Kelimeler: Fen \\
öğretimi, Yapılandırmacı \\
yaklaşım, Öğrenme halkası \\
modeli, Meta analiz, Öğrenme \\
ürünleri \\
Makale Geçmişi: \\
Geliş: 13 Nisan 2017 \\
Düzeltme: 28 Ağustos 2017 \\
Kabul: 26 Ekim 2017 \\
Makale Türü: Araştırma \\
Makalesi
\end{tabular}




\section{The Effect of Learning Cycle Models Usage on Students’ Learning Outcomes at Science: Meta- Analysis Study}

\begin{tabular}{|c|c|}
\hline Abstract & Article Info \\
\hline $\begin{array}{l}\text { In the study, meta-analysis study is carried out in order to determine the effect of learning } \\
\text { cycle models usage on students' learning outcome sat science: Master thesis and PhD } \\
\text { dissertation consisting of statistical data which can be included in meta-analysis study and } \\
\text { appropriate to research problem done in the years between } 2007 \text { and } 2016 \text { in the literature } \\
\text { through using Turkish and English words from national data base. As a consequence of } \\
\text { literature review, totally } 107 \text { studies ( } 50 \text { PhD dissertations and } 57 \text { Master theses) related to } \\
\text { the effect of learning cycle models usage on students' learning outcomes are included in } \\
\text { meta-analysis and the effect size of } 227 \text { is obtained in total. As a result of the research, it } \\
\text { is confirmed that the effect of learning cycle models usage on students' learning outcomes } \\
\text { is in positive way and the determined effect size is found out as .967 (95 \% CI, SE = } \\
\text {.054) in the confidence interval .862 and } 1.072 \text { according to random effects model. This } \\
\text { size is an extensive effect size in accordance with effective size classification. 209 of the } \\
\text { effect size } 227 \text { obtained in the study is positive and } 18 \text { of it is negative. Moderator } \\
\text { analysis is carried out with regard to students' learning outcomes, the learning cycle } \\
\text { models type, the thesis type and discipline field of the research and education levels of } \\
\text { students included in the research. In consequence of analyses, the highest effect size is } \\
\text { found out as (ES = 1.521) in the memorability of learned knowledge, (ES = 2.289) in } 4 \mathrm{E} \\
\text { model studies, (ES = 1.081) in post-graduate dissertations studies, (ES = 1.118) in science } \\
\text { and (ES = 1.540) in Primary school students. }\end{array}$ & $\begin{array}{l}\text { Article History: } \\
\text { Received: } 13 \text { April } 2017 \\
\text { Revised: } 28 \text { August } 2017 \\
\text { Accepted: } 26 \text { October } 2017 \\
\text { Article Type: Research Article }\end{array}$ \\
\hline
\end{tabular}




\section{Giriş}

Bireyler yaşadıkları toplumun bir parçasıdırlar ve toplumla karşılıklı bir etkileşim halindedirler. Hem toplumdan etkilenen hem de yaşadığı toplumu etkileyen konumda olan birey, topluma ait değerlerin, ortak temel davranış Wittrock tarafindan geliştirilen ve Ausubel’in "öğrenmeyi etkileyen en önemli faktör öğrencinin mevcut bilgi birikimidir” şeklinde ifade edilen düşüncesine dayanan yapılandırmacı öğrenme yaklaşımı, temelde öğrencilerin mevcut bilgilerini kullanarak yeni bilgiler edinmelerini, öğrenmeyi ve kendine özgü bilgi oluşturmayı açılamaya çalışan bir öğrenme yaklaşımı olarak karşımıza çıkmaktadır (Appleton, 1997; Hand \& Treagust, 1991). Yapılandırmacı öğrenme yaklaşımının temeli, bilgilerin doğrudan bireylere aktarımı yerine, bu bilgilerin bireylerin sahip olduğu ön bilgilerle ilişkilendirmesi sağlanarak kendilerinin yapılandırması gerektiği görüşüne dayanmaktadır (Akpınar ve Ergin, 2005). Buna göre bilginin, bireyin zihninde oluşması ve bireyin bilgiyi kişisel özelliklerine göre anlamlandırması ve yapılandırmasıdır (Demirel \& Yurdakul, 2007). Yapılandırmacı öğrenme yaklaşımı genel olarak “dışarıdan alınan bilgiler zihnimize nasıl yerleşir?”, "bu bilgileri zihnimizde nasıl işler ve kendimize mal ederiz?” ve “önceki bilgilerimizle çelişen yeni bilgiler zihnimizde yapılanırken ne gibi değişiklikler olur?” sorularına cevap aramaktadır (Baker \& Piburn, 1997; Çepni, Akdeniz, \& Keser, 2000).

Yapılandırmacı öğrenme yaklaşımının en önemli savunucularından Bodner (1990) öğrenme ve öğretmenin eş anlamlı kelimeler olmadığını, öğretmenlerin çok iyi öğretici olsalar bile, öğrencilerin her zaman öğrenemeyeceklerini vurgulamıştır. Bodner'a göre bilgi öğrenenin kafasında yapılandırılır ve bilginin öğretmenin kafasından öğrencinin kafasına hiçbir değişikliğe uğramadan geçme şansı çok azdır. Başka bir ifade ile öğrencilerin okuldaki eğitim-öğretim ortamlarında kazandıkları bilgiler onların bu ortama gelmeden önce sahip oldukları ön bilgilere ve eğitim-öğretim ortamının onlara sağladıklarına bağlıdır. Bu nedenle öğrencilerin ön bilgileri ve varsa yanlış kavramaları ciddi bir şekilde ortaya çıkarılmalı ve öğretim bunların dikkate alınmasıyla planlanmalıdır (Eisenkraft, 2003).

Milli Eğitim Bakanlığ1 (MEB) 2004-2005 eğitim-öğretim döneminden itibaren eğitimde bireysel farklılıklara verilen önemin artması sonucunda yapılandırmacı yaklaşımın ön plana çıktı̆̆ı bir öğretim planı uygulamaya koymuştur (Tonbuloğlu, 2014). Yapılandırmacı yaklaşımın eğitim-öğretim alanında uygulanması öğrenme halkası modelleri ile olmaktadır. Fen eğitimi alanında yapılan araştırmalarda, öğrenme halkası modellerinin öğrencilerin bilgiyi tanıması, öğrendiği bilginin içeriğini anlaması ve bilimsel süreçleri uygulaması bakımından etkili modellerden olduğu vurgulanmaktadır (Wilder \& Shuttleworth, 2004). Öğrenme halkası esnek bir modeldir. Buna göre, öğrenme aşamalarının formatı değiştirilebilir fakat sırası değiştirilemez ve aşamaların hiçbiri atlanamaz. Öğrenme halkası modeli aşamaları, öğrencilerin ön bilgilerini sınamalarına imkan veren yeni durumlar hakkında tartışmalarına ve bunları test etmelerine firsat verir (Renner, Abraham, \& Birnie, 1998).

Öğrenme halkası modeli, başlangıçta keşif, terim tanıtımı ve kavram uygulamalarından oluşan 3E modeli olarak başlamış, daha sonra merak uyandırma, keşfetme, açıklama ve genişletme şeklinde 4E öğrenme halkası modeli olarak ifade edilmiştir (Bybee, 1997). İlerleyen yıllarda fen eğitim araştırmacıları tarafindan ilave olarak değerlendirme aşaması eklenerek 5E öğrenme halkası modeli şeklinde geliştirilmiştir (Boddy, Watson, \& Aubusson, 2003). Daha sonraları öğrenme halkası modelleri üzerine çalışmalar yapan Bybee (2003) ve Eisenkraft (2003), 5E öğrenme halkası modelini geliştirerek 7E öğrenme halkası modeli olacak şekilde yeniden yorumlamışlardır. Her iki araştırmacıda temelde aynı düşünceler etrafında birleşmiş olmalarına rağmen, bazı aşamaları özellikle vurgulamışlardır (Kanlı, 2009). Bybee, geliştirmiş olduğu 5E modeline ilave olarak "İlişkilendirme-uzatma" aşamasını ve "Fikir alış verişi-paylaşma" aşamalarını ilave etmiştir. Eisenkraft ise 5E modeline ilave olarak, önce "Ön bilgileri yoklama" aşamasını ve en sonunda ise "İlişkilendirme" aşamasını eklemiştir. Bu durumda 7E öğrenme halkası modelinin aşamaları Bybee'ye (2003) göre, merak uyandırma, keşfetme, açıklama, genişletme, ilişkilendirme, paylaşma ve değerlendirme şeklindedir. Eisenkraft'a (2003) göre ise, ön bilgileri yoklama, merak uyandırma, keşfetme, açıklama, derinleştirme, değerlendirme ve ilişkilendirme şeklindedir.

Alan yazında, yapılandırmacı yaklaşım öğrenme modellerine göre hazırlanan öğretim materyallerinin fen bilimleri alanında kullanımına ilişkin öğrencilerin öğrenme ürünlerine etkisi (Bulut, 2012; Çoruhlu \& Çepni, 2016; Harurluoğlu \& Kaya, 2011, Küçük \& Çalık, 2015; Meşeci \& Karamustafaoğlu, 2015; Turgut, Gürbüz, \& Salar, 2013; Turgut, Çolak, \& Sala, 2016; Saraç, 2015; Yenice, 2014), öğretim materyali geliştirme sürecine katkısı (Balım, Türkoğuz, Aydın, \& Evrekli, 2012; Çepni, Akdeniz, \& Keser, 2000; Çepni, Şan, Gökdere, \& Küçük, 2001; Kanlı, 2009; Saraç, 2015; Şadoğlu \& Akdeniz, 2015), derse olan ilgi, beceri ve tutumlarına olan etkisi (Demir \& Maskan, 2012; Özaydın, 2010; Şaşmaz-Ören \& Tezcan, 2009; Temel, Özgür, \& Yılmaz, 2012), öğretmen, öğretmen adayı ve 
öğrenci görüşleri (Bilgin, Ay, \& Coşkun, 2013; Demir \& Maskan, 2014; Saraç, 2015) ve alan yazın taraması (Keleş, 2010; Özmen, 2004; Türkmen, 2006) üzerine birçok çalışma yapılımıştır. Ayrıca, yapılandırmacı yaklaşım öğrenme halkası modelleri alanında "Yapılandırmacı Yaklaşım 7E Öğrenme Halkası Modeli İle İlgili Yapılan Araştırmalar: İçerik Analizi Çalışması" (Saraç \& Kunt, 2016) ve "Fen Eğitiminde 5E Modeli İle İlgili Yazılı Kaynaklar Dizini”" (Ergin, 2012) şeklinde içerik analizi çalışmaları da mevcuttur.

Ulusal alan yazında Fen öğretiminde meta analiz yöntemi kullanılarak öğrencilerin, akademik başarıya (Aktamış \& Özden, 2016; Ayaz, 2015; Balta \& Saraç, 2016; Bozdemir, Çevik, Altunoğlu, \& Kurnaz, 2017; Dinçer \& Güçlü, 2013; Karakuş \& Öztürk, 2016; Saraç, 2017; Ural \& Bümen, 2016; Yeşilyurt, 2011), öğrenilen bilgilerin kalıcılı̆̆ına (Saraç, 2017), derslere olan tutumlarına (Aktamış \& Özden, 2016; Ayaz, 2015; Ayaz \& Söylemez, 2015; Ayaz \& Şekerci, 2016; Karakuş \& Öztürk, 2016; Saraç, 2017; Ural \& Bümen, 2016) ve bilimsel süreç becerilerine (Aktamış \& Özden, 2016) etkisine yönelik çalışmalar yapılmıştır. Bu çalışmalardan elde edilen sonuçlar genel olarak Tablo 1'de gösterilmiştir.

Tablo 1. Fen Öğretimi Alanında Yapılan Meta Analiz Çalışmaları

\begin{tabular}{|c|c|c|c|c|}
\hline Araştırmacılar & Araştırma İçeriği & Öğrenme Ürünleri Alanı & $\begin{array}{c}\text { EB } \\
\text { değeri }\end{array}$ & $\begin{array}{c}\text { EB } \\
\text { seviyesi* }^{*}\end{array}$ \\
\hline $\begin{array}{c}\text { Bozdemir, Çevik, Altunoğlu ve } \\
\text { Kurnaz (2017) }\end{array}$ & Fen Öğretiminde Astronomi & Akademik Başarı & 0.82 & Geniş düzey \\
\hline Saraç (2017) & $\begin{array}{l}\text { Eğitim ve Öğretimde } \\
\text { Akıllı Tahta Kullanımı }\end{array}$ & $\begin{array}{c}\text { Akademik Başarı } \\
\text { Kalıc1lık } \\
\text { Tutum } \\
\end{array}$ & $\begin{array}{l}0.809 \\
1.009 \\
0.807 \\
\end{array}$ & $\begin{array}{l}\text { Geniş düzey } \\
\text { Geniş düzey } \\
\text { Geniş düzey }\end{array}$ \\
\hline Aktamış ve Özden (2016) & $\begin{array}{l}\text { Fen Öğretiminde Araştırma ve } \\
\text { Sorgulamaya Dayalı Öğrenme }\end{array}$ & $\begin{array}{c}\text { Akademik Başarı } \\
\text { Tutum } \\
\text { Bilimsel Süreç Becerileri } \\
\end{array}$ & $\begin{array}{l}1.029 \\
0.053 \\
0.742 \\
\end{array}$ & $\begin{array}{l}\text { Geniş düzey } \\
\text { Orta düzey } \\
\text { Orta düzey }\end{array}$ \\
\hline Balta ve Saraç (2016) & 7E Modeli Kullanımı & Akademik Başarı & 1,240 & Çok geniş \\
\hline Öztürk ve Karakuş (2016) & $\begin{array}{c}\text { Fen Öğretiminde İşbirliğine } \\
\text { Dayalı Öğrenme }\end{array}$ & $\begin{array}{c}\text { Akademik Başarı } \\
\text { Tutum }\end{array}$ & $\begin{array}{l}0.694 \\
0.210 \\
\end{array}$ & $\begin{array}{c}\text { Orta düzey } \\
\text { Küçük düzey }\end{array}$ \\
\hline Ural ve Bümen (2016) & $\begin{array}{c}\text { Fen Öğretiminde } \\
\text { Yapılandırmacılık } \\
\end{array}$ & $\begin{array}{c}\text { Akademik Başarı } \\
\text { Tutum }\end{array}$ & $\begin{array}{l}1.003 \\
0.743\end{array}$ & $\begin{array}{l}\text { Geniş düzey } \\
\text { Orta düzey }\end{array}$ \\
\hline Ayaz (2015a) & 5E Modeli Kullanımı & Tutum & 0.37 & Küçük düzey \\
\hline Ayaz (2015b) & $\begin{array}{c}\text { Fen Öğretiminde Probleme } \\
\text { Dayalı Öğrenme }\end{array}$ & Akademik Başarı & 1.206 & Çok geniş \\
\hline Ayaz ve Söylemez (2015) & $\begin{array}{l}\text { Fen Öğretiminde Proje } \\
\text { Temelli Öğrenme }\end{array}$ & Tutum & 0.997 & Geniş düzey \\
\hline Ayaz ve Şekerci (2015) & Yapılandırmacı Yaklaşım & $\begin{array}{c}\text { Akademik Başarı } \\
\text { Tutum }\end{array}$ & $\begin{array}{l}1.156 \\
0.755\end{array}$ & $\begin{array}{l}\text { Çok geniş } \\
\text { Orta düzey }\end{array}$ \\
\hline Dinçer ve Güçlü (2013) & $\begin{array}{c}\text { Fen Öğretiminde Bilgisayar } \\
\text { Destekli Simülasyon } \\
\text { Kullanımı } \\
\end{array}$ & Akademik Başarı & 1.47 & Mükemmel \\
\hline Yeşilyurt (2011) & $\begin{array}{c}\text { Fizik Dersinde } \\
\text { Bilgisayar Destekli Öğretim }\end{array}$ & Akademik Başarı & 3.17 & Mükemmel \\
\hline
\end{tabular}

* Thalheimer ve Cook (2002) siniflamasina göre

Alan yazında yapılandırmacı yaklaşım öğrenme halkası modelleri kullanılarak genel olarak öğrencilerin öğrenme ürünlerine etkisi ile ilgili bir meta analiz çalışmasına rastlanılmamıştır. Bu yüzden çalışmanın öğrencilerin akademik başarısı, öğrenilen bilgilerin akılda kalıcı olması, derse olan tutumları ve bilimsel süreç becerileri alanında alan yazına katkı sağlayacağı düşünülmektedir.

\section{Araştırmanın Amacı}

Araştırmanın amacı, fen öğretiminde yapılandırmacı yaklaşım öğrenme halkası modelleri kullanımının öğrencilerin akademik başarısına, öğrenilen bilgilerin kalıcılı̆̆ına, derse olan tutumuna ve bilimsel süreç becerileri gelişimine etkisini meta analiz çalışması ile tespit etmektir. Bunun için ulusal alanda, fen öğretimi sürecinde ve lisansüstü düzeyde yapılan tez araştırmalarında yapılandırmacı yaklaşım öğrenme halkası modelleri kullanılarak yapılan çalışmaların etki büyüklükleri analiz edilmiştir. 


\section{Araştırmanın problemi}

Buna göre araştırmada, "Fen öğretimi sürecinde yapılandırmacı yaklaşım öğrenme halkası modelleri kullanımının öğrencilerin öğrenme ürünlerine olan etki büyüklüğü nasıldır?” sorusuna cevap aranmıştır. Bu doğrultuda belirlenen alt problemler şu şekildedir.

- Ulusal alanda fen öğretimi sürecinde öğrenme halkası modelleri kullanımı ile yapılan çalışmaların ögrencilerin akademik başarısına etkisi var mıdır?

- Ulusal alanda fen öğretimi sürecinde öğrenme halkası modelleri kullanımı ile yapılan çalışmaların öğrencilerin öğrendikleri bilgilerin kalıcılığına etkisi var mıdır?

- Ulusal alanda fen öğretimi sürecinde öğrenme halkası modelleri kullanımı ile yapılan çalışmaların öğrencilerin derse olan tutuma etkisi var mıdır?

- Ulusal alanda fen öğretimi sürecinde öğrenme halkası modelleri kullanımı ile yapılan çalışmaların öğrencilerin bilimsel süreç becerileri gelişimine etkisi var mıdır?

- Ulusal alanda fen öğretimi sürecinde öğrenme halkası modelleri kullanımı ile yapılan çalışmaların öğrencilerin öğrenme ürünlerine olan etkisi kullanılan modele göre değişmekte midir?

- Ulusal alanda fen öğretimi sürecinde öğrenme halkası modelleri kullanımı ile yapılan çalışmaların öğrencilerin öğrenme ürünlerine olan etkisi lisansüstü tez türüne göre değişmekte midir?

- Ulusal alanda fen öğretimi sürecinde öğrenme halkası modelleri kullanımı ile yapılan çalışmaların öğrencilerin öğrenme ürünlerine olan etkisi fen alanlarına göre değişmekte midir?

- Ulusal alanda fen öğretimi sürecinde öğrenme halkası modelleri kullanımı ile yapılan çalışmaların öğrencilerin öğrenme ürünlerine olan etkisi öğrencilerin öğrenim düzeylerine göre değişmekte midir?

\section{Yöntem}

\section{Araştırma Modeli}

Araştırmada ulusal alanda, fen öğretimi sürecinde yapılandırmacı yaklaşım öğrenme halkası modelleri kullanımının etkililiğini tespit etmek için meta analiz çalışması yapılmıştır. Meta analiz yönteminde, herhangi bir alanda yapılmış deneysel-yarı deneysel çalışmalardan elde edilen nicel verilerin uyumlu bir şekilde istatistiksel yöntemler kullanılarak değerlendirilmesi, kıyaslanması ve birleştirme yapılarak bağımsız değişkenin bağımlı değişken üzerindeki etkisinin hesaplanmasıdır (Cohen, Manion, \& Marrison, 2007). Dinçer (2015), meta analizi "bir konu, tema veya çalışma alanı ile ilgili benzer çalışmaların, belirlenen ölçütler altında toplanıp, gruplandırılarak elde edilen nicel verilerin birleştirilerek yorumlanması" olarak ifade etmiştir.

Meta analiz yönteminin grup karşılaştırma ve korelasyonel ilişki olmak üzere iki tür analiz biçimi vardır. Bu araştırmada grup karşılaştırma meta analiz yöntemlerinden biri olan işlem etkililiği meta analiz yöntemi kullanılmıştır. İşlem etkililiği meta analiz yöntemi, çoklu çalışmalarda kullanılan bağımsız araştırmalara ait olan verilerin ortak bir ölçme sistemine çevrilerek elde edilen etki büyüklüğü değerlerinin karşılaştırılmasıdır (Şahin, 2005).

\section{Verilerin Toplanması}

Araştırmaya dahil edilen çalışmalar, son on yıl olan 2007-2016 yılları arasında ulusal alanda fen öğretimi sürecinde yapılandırmacı yaklaşım öğrenme halkası modelleri kullanılarak yapılan yayımlanmış istatistiksel değerlendirilmesi yapılmış ve gerekli nicel verilere (deney ve kontrol grubuna ait örneklem büyüklügü̈, ön test/son test aritmetik ortalama ve standart sapma değeri, t-testi sonuçları vb. ) sahip doktora ve yüksek lisans tezlerinden oluşmaktadır. Erişim izni olmayan lisansüstü tezler araştırmaya dahil edilmemiştir.

Ulusal alanda yapılan lisansüstü tezlerin taraması Türkçe ve İngilizce olarak Ulusal Tez Merkezi-YÖK internet sitesinden 1 Ocak 2017 ile 15 Nisan 2017 tarihleri arasında yapılmıştır. Tarama sırasında lisansüstü tezlerin adında ve anahtar kelimelerinde Türkçe olarak, "Öğrenme halkası modeli”, “Öğrenme döngüsü modeli”, "3E Modeli”, “4E Modeli”, “5E Modeli” ve "7E Modeli” ve İngilizce olarak "Learning Cycle Model”, "3E Model”, “4E Model”, "5E Model” ve "7E Model” ifadeleri içeren tezler dikkate alınarak tarama yapılmıştır. Tarama sonucu 187 adet lisansüstü tez tespit edilmiş̧ir. Tespit edilen lisansüstü tezler araştırmanın amacına uygun olarak inceleme yapıldığında ulusal alanda istenilen ölçütlere uygun 50 doktora tezi ve 57 yüksek lisans tezi olmak üzere toplamda 107 lisansüstü tez araştırmaya dahil edilmiştir. 
Araştırmada, öğrencilerin akademik başarısına, öğrenilen bilgilerin kalıcılığına, derse olan tutuma ve bilimsel süreç becerilerini geliştirmeye yönelik yayınlanan 50 doktora tezinden 121 adet, 57 yüksek lisans tezinden 107 adet olmak üzere toplamda 227 farklı çalışmanın (Ek-1) etki büyüklüğü değeri hesaplanarak meta analiz yöntemine dahil edilmiştir.

\section{Araştırmaya Dahil Edilme Kriterleri:}

1. Çalışmanın 2007-2016 yılları arasında yapılması

2. Çalışmanın ulusal alanda yapılmış olması ve erişim izinlerinin olması

3. Çalışmanın ulusal alanda doktora tezi ve yüksek lisans tezi olarak yayımlanmış olması

4. Çalışmada deneysel veya yarı-deneysel yöntemlerin kullanılması

5. Deney gruplarına öğrenme halkası modellerine göre hazırlanan materyaller kullanılarak, kontrol gruplarına ise geleneksel yöntemler kullanılarak derslerin anlatılması.

6. Çalışmada öğrencilerin akademik başarısının, öğrenilen bilgilerin kalıcılığının, derse olan tutumunun ve bilimsel süreç becerilerinin incelenmesi

7. Çalışmada etki büyüklügünün hesaplanabilmesi için gerekli istatistiksel verilerin sunulması

8. Çalışmanın Fen öğretimi alanında yapılmış olması

Verilerinin Kodlanması: Araştırmada tespit edilen çalışmaların meta analiz yöntemine dahil edilme özelliklerinin ve uygunluğunun incelenmesi, çalışmalar arası karşılaştırmalar yapılabilmesi ve araştırmada kullanılan istatistik bilgilerin belirlenebilmesi için araştırmanın amacına uygun kodlama formu araştırmacı tarafından geliştirilmiştir. Düzenlenen kodlama formunda yer alan bilgiler, çalışmaların genel özelliklerini yansıtacak şekilde belirlenmiştir. Formda yer alan özellikler şu şekildedir; Çalışmanın adı, çalışmanın yazarı, çalışmanın yayın türü, çalışmada kullanılan öğrenme halkası modeli, çalışmanın öğrenme ürünleri hedefi, çalışmanın disiplin alanı, çalışmanın yayınlandığı yıl, çalışmanın uygulama süresi, çalışmaya katılan öğrencilerin öğrenim seviyesi, çalışmanın örneklem büyüklüğü ve analiz yöntemleri ile çalışmaya ait nicel verilerden elde edilen istatistik bilgileri vb...

Meta analiz yönteminde amaca yönelik tespit edilen çalışmalar için oluşturulan kodlama formunun doldurulması, kodlama güvenirliği için çok önemlidir. Bunun için tespit edilen çalışmalar alanında uzman en az iki kişi tarafından incelenmesi ve kodlama formlarının doldurulması gerekir (Açıkel, 2009). Araştırmada, çalışmalara ait kodlama formları eğitim bilimleri alanında doktorasını tamamlamış iki uzman tarafından doldurulmuştur. Kodlama sonrası her iki uzmana ait formlar karşılıklı olarak değerlendirilmiştir. Değerlendirme sonucunda kodlamaların güvenirliği, Miles ve Huberman'ın (2002) geliştirdiği güvenlik düzeyi formülüne göre \% 96 seviyesinde olduğu hesaplanmıştır. Güvenirlik düzeyi formülüne göre $\% 70$ ve üstü sonuçlar güvenirlik için yeterli olmaktadır (Yıldırım \& Şimşek, 2011). Buna göre, araştırmanın amacına yönelik tespit edilen çalışmalara ait yapılan kodlamaların güvenilir olduğu ifade edilebilir.

Bağımlı ve Bağımsız Değişkenler: Araştırmada meta analiz yöntemine dahil edilen çalışmaların öğrencilerin akademik başarısına, öğrenilen bilgilerin kalıcılığı, derse olan tutuma etkisi ve bilimsel süreç becerilerine yönelik hesaplanan etki büyüklükleri araştırmanın bağımlı değişkenini oluşturmaktadır. Araştırmanın bağımsız değişkeni ise ders anlatım metodudur (öğrenme halkası modellerine göre hazırlanan materyallerin kullanımı ve geleneksel öğretim yöntemleri). Buna göre öğrenme halkası modellerinin kullanımı ve geleneksel öğretim yöntemlerinin (bağımsız değişken) öğrenme ürünleri (bağımlı değişken) üzerindeki etkileri bu çalışmada incelenmiştir.

\section{Verilerinin Analizi}

Araştırmada yayımlanmış doktora ve yüksek lisans tezleri dikkate alınarak kalite sorunu çözülmeye çalışılmıştır. Meta analiz yönteminde, tespit edilen çalışmaların sonuçlarının istatistiksel olarak birleştirilmesi gerekir. Önce hangi istatistiksel modelin kullanılacağına karar verilmelidir. Bunun için Hedges ve Olkin'in (1985) geliştirdiği Q istatistiklerinden yararlanılır. Q istatistiklerine göre Sabit Etkiler Modeli (SEM) ve Rastgele Etkiler Modeli (REM) olmak üzere iki model vardır. SEM'de her çalışma için bir gerçek etki büyüklüğü vardır. REM'de araştırmaya katılan çalışmaların etki büyüklüklerinin ortalamasını tahmin eden bir modeldir (Borenstein, Hedges, Higgins, \& Rothstein, 2013).

Meta analiz yönteminde hangi istatistiksel modelin kullanılacağına etki büyüklüklerinin homojen dağılım gösterip-göstermediğine bakılır. Q homojenlik testine ait p değerinin ,05’ten büyük olması dağılımın homojen 
olduğunu ve dolayısıyla sabit etki modeli (SEM), bu değerin .05'in altında olduğu durumlarda ise rastgele etki modeli (REM) kullanılır (Ellis, 2010). Heterojen dağılımın ölçüsü ise $\mathrm{I}^{2}$ istatistik testi ile daha açık şekilde sonuç verebilir. $\mathrm{I}^{2}$ sonucuna göre $\% 25$ 'e kadar düşük düzeyde heterojenliği, \%50 civarı orta düzeyde heterojenliği ve \%75 üstü ise yüksek düzeyde heterojenliği gösterir (Cooper, Hedges, \& Valentine, 2009).

Meta analiz yönteminde tespit edilen çalışmalara ait etki büyüklükleri Thalheimer ve Cook (2002) tarafindan önerilen Cohen's $d$ ile Hedges ve Olkin (1985) tarafindan önerilen Hedges' $g$ şeklinde hesaplanmaktadır. Meta analiz yönteminde hesaplanan etki büyüklüklerinin büyüklükleri yorumlanırken sınıflandırmalar kullanılır. Araştırmada elde edilen etki büyüklüğü değerlerine ait ölçek geniş boyutta olduğundan Thalheimer ve Cook (2002) tarafindan belirtilen düzey sinıflandırmaları kullanılmıştır. Buna göre;

- Etki büyüklügüü ,15 ve küçük ise önemsiz düzeyde,

- ,15’den büyük ,40 arasında ise küçük düzeyde,

- ,40’dan büyük ve ,75 arasinda ise orta düzeyde,

- ,75’den büyük ve 1,10 arasında ise geniş düzeyde,

- 1,10'dan büyük ve 1,45 arasında ise çok geniş düzeyde,

- 1,45 'den büyük ise mükemmel düzeydedir.

Etki büyüklüğü değerlerinin pozitif çıkması değerlendirilen performans boyutunun deney grubu lehine olduğunu, negatif çıkması ise değerlendirilen performans boyutunun kontrol grubu lehine olduğunu gösterir (Wolf, 1988).

Meta analiz yönteminde tespit edilen çalışmaların yayın yanlılığın tespit edilmesi için Orwin yöntemi ve huni grafiği yöntemi kullanılır. Orwin yönteminde genel etki büyüklüğü değerinin sıfıra düşmesi için ortalama etki büyüklüğü sıfır olan çalışma sayısı hesaplanır (Lipsey \& Wilson, 2001). Ayrıca huni grafiği de (Funnel Plot) kullanılarak yayın yanlılığı hakkında fikir edinilebilir. Huni grafiği, X ekseninde araştırmaya katılan her bir çalışmanın etki büyüklüğ̈̈ değeri, Y ekseninde ise çalışmalara ait örneklem büyüklüğü, varyans veya standart hatayı gösterecek şekilde oluşturulur. Grafiğe göre araştırmaya katılan çalışmalar genel etki büyüklüğüne göre simetrik dağılım gösteriyor ise çalışmanın güvenilir olduğuna yani yayın yanlılığının olmadığına karar verilir (Üstün \& Eryılmaz, 2014).

Meta analiz yönteminde son olarak, Fen öğretimi sürecinde yapılandırmacı yaklaşım öğrenme halkası modelleri kullanımının etkililiğinin değişebileceği çeşitli alt gruplar belirlenmiştir. Bu gruplar; öğrenme halkası model türleri, öğrenme ürünleri kategorileri, lisansüstü tez türleri, çalışmanın yapıldığı Fen alanı ve çalışmaya katılan öğrencilerin öğrenim düzeyleridir. Bu alt gruplara ait analizler yapılmış ve sonuçları rapor edilmiştir.

\section{Bulgular}

$\mathrm{Bu}$ araştırmada toplam 107 lisansüstü tez çalışmasından 227 tane etki büyüklüğü değeri hesaplanmıştır. 121 etki büyüklüğü doktora tezlerinden, 106 tanesi ise yüksek lisans tezlerinden elde edilmiştir. Meta-analize dahil edilen çalışmaların deney gruplarında toplam 9006 öğrenci ve kontrol gruplarında toplam 8892 öğrenci mevcuttur. Çalışmalar alt gruplara ayrıldığında; öğrenme ürünleri alanında öğrenme halkası modeli kullanımının akademik başarıya etkisi alanında 106, öğrenilen bilgilerin kalıcılığına etkisi alanında 24, derse olan tutuma etkisi alanında 64 çalışma ve bilimsel süreç becerileri alanında ise 33 çalışma; yapılandırmacı yaklaşım öğrenme halkası modellerinden 3E modeli alanında 18, 4E modeli alanında 7, 5E modeli alanında 173 ve 7E modeli alanında ise 29 çalışma; Fen alanında fen bilimleri dersinde 113, fizik dersinde 38, kimya dersinde 46 ve biyoloji dersinde 30 çalışma; öğrenim düzeyinde ilkokullarda 12, ortaokullarda 101, liselerde 83 ve üniversitelerde 31 çalışma tespit edilmiştir. Tespit edilen 227 çalışmanın etki büyüklükleri değerlerinin homojen dağılım gösterip göstermediği Tablo 2'de sunulmuştur.

Tablo 2. Çalışmaların Etki Büyüklüklerine Ait Bulgular

\begin{tabular}{|c|c|c|c|c|c|c|c|c|c|c|}
\hline \multirow[t]{2}{*}{ Model } & \multirow[t]{2}{*}{$\mathbf{N}$} & \multirow[t]{2}{*}{ EB } & \multirow[t]{2}{*}{ df } & \multirow[t]{2}{*}{ (Q) } & \multirow{2}{*}{$\begin{array}{c}\text { Standart } \\
\text { Hata }\end{array}$} & \multirow[t]{2}{*}{$\mathbf{Z}$} & \multirow[t]{2}{*}{$\mathbf{p}$} & \multirow[t]{2}{*}{$\mathbf{I}^{2}$} & \multicolumn{2}{|c|}{$\begin{array}{c}\text { Etki Büyüklüğü İçin \%95'lik } \\
\text { Güven Aralığı }\end{array}$} \\
\hline & & & & & & & & & Alt sinır & Üst sınır \\
\hline SEM & 227 & ,792 & 226 & 2429,72 & ,016 & 49,32 & ,00 & 90,69 & ,761 & ,824 \\
\hline REM & 227 & ,967 & & & ,054 & 18,01 & ,00 & & ,862 & 1,072 \\
\hline
\end{tabular}


Araştırmaya dâhil edilen çalışmaların homojenlik değeri sabit etkiler modeline (SEM) göre Q=2429,72 ve $\mathrm{p}=$ ,00 olarak bulunmuştur. P değerinin \% 95 anlamlılık düzeyine göre ,05'den küçük olması bağımsız değişkenler arasında istatistiksel olarak anlamlı bir farkın olduğunu ortaya koymaktadır. Bu nedenle çalışmaların etki büyüklüğü değerlerinin heterojen yapıda olduğu görülmektedir. Bundan dolayı bu çalışmada analizler rastgele etkiler modeline (REM) göre yapılmıştır.

Rastgele etkiler modeline (REM) göre yapılan analiz sonucunda ortalama etki büyüklüğü değeri ,054 standart hata ile ,967olarak bulunmuştur. \% 95 güven aralığında etki büyüklüğünün alt sınırı 0,862, üst sınırı 1,072 olarak hesaplanmıştır. Ortalama etki büyüklüğü değerinin pozitif çıkması, 5E öğrenme modeli kullanılarak işlenen derslerin geleneksel yöntemlere göre daha etkili olduğunu göstermektedir. Bu etki Thalheimer ve Cook (2002) sınıflandırmasına göre geniş düzeyde bir etkiyle sahiptir.

Birincil çalışmalarda yer alan akademik başarnya ait etki büyüklüğü sabit etkiler modeline (SEM) ve rastgele etkiler modeline (REM) göre değerleri Tablo 3'de, bu değerlerin dağılımını gösteren orman grafiği ise Şekil 1'de gösterilmiştir.

Tablo 3. Çalışmaların Akademik Başarı Etki Büyüklüklerine Ait Bulgular

\begin{tabular}{|c|c|c|c|c|c|c|c|c|c|c|}
\hline \multirow[t]{2}{*}{ Model } & \multirow[t]{2}{*}{$\mathbf{N}$} & \multirow[t]{2}{*}{ EB } & \multirow[t]{2}{*}{ df } & \multirow{2}{*}{ (Q) } & \multirow{2}{*}{$\begin{array}{l}\text { Standart } \\
\text { Hata }\end{array}$} & \multirow[t]{2}{*}{$\mathbf{Z}$} & \multirow[t]{2}{*}{$\mathbf{p}$} & \multirow[t]{2}{*}{$\mathbf{I}^{2}$} & \multicolumn{2}{|c|}{$\begin{array}{l}\text { Etki Büyüklüğğ İçin } \\
\text { \%95'lik Güven Aralığı }\end{array}$} \\
\hline & & & & & & & & & Alt sinır & Üst sınır \\
\hline SEM & 106 & ,996 & 105 & 1061,17 &, 024 & 41,53 & 00 & 90,10 & 949 & 1,043 \\
\hline REM & 106 & 1,17 & & & ,078 & 15,03 & ,00 & & 1,018 & 1,323 \\
\hline
\end{tabular}

Araştırmaya dâhil edilen akademik başarıya ait çalışmaların homojenlik değeri sabit etkiler modeline göre $\mathrm{Q}=1061,17$ ve $\mathrm{p}=, 00$ olarak bulunmuştur. $\mathrm{P}$ değerinin \% 95 anlamlılık düzeyine göre, 05 'den küçük olması bağımsız değişkenler arasında istatistiksel olarak anlamlı bir farkın olduğunu ortaya koymaktadır. Bu nedenle akademik başarıya ait çalışmaların etki büyüklüğü değerlerinin heterojen yapıda olduğu görülmektedir. Rastgele etkiler modeline (REM) göre yapılan analiz sonucunda ortalama etki büyüklüğü değeri ,078 standart hata ile 1,170 olarak bulunmuştur. Bu etki Thalheimer ve Cook (2002) sınıflandırmasına göre çok geniş düzeyde bir etkiyle sahiptir.

Grafikte siyah karelerin orta dikey çizgiye göre bulunduğu konum akademik başarı çalışmalarının etki büyüklüğünü, karelerin iki yanındaki çizgiler \%95 güven aralığının alt ve üst limitlerini göstermektedir. Karelerin büyüklüğü ait oldukları çalışmaların genel etki büyüklüğü içindeki ağırlığını göstermektedir. Şeklin en aşağısında bulunan eşkenar dörtgen olan elmas, çalışmaların rastgele etkiler modeline (REM) göre genel etki büyüklüğünü göstermektedir.

Akademik başarı çalışmalarına ait etki büyüklükleri incelendiğinde en küçük etki büyüklüğü değerinin -,906 (Yıldız, 2008), en yüksek etki büyüklüğü değerinin ise 5,450 (Okur, 2009) etki alanında olduğu belirlenmiştir. Çalışmaların etki büyüklüklerine bakıldığında 106 etki büyüklüğünün 101 'i pozitif, 5'i ise negatif etki değerine sahiptir.

Birincil çalışmalarda yer alan öğrenilen bilgilerin kalıcılığına ait etki büyüklüğü sabit etkiler modeline (SEM) ve rastgele etkiler modeline (REM) göre değerleri Tablo 4'de, bu değerlerin dağılımını gösteren orman grafiği ise Şekil 2'de gösterilmiştir.

Tablo 4. Çalışmaların Kalıcılık Etki Büyüklüklerine Ait Bulgular

\begin{tabular}{|c|c|c|c|c|c|c|c|c|c|c|}
\hline \multirow[t]{2}{*}{ Model } & \multirow[t]{2}{*}{$\mathbf{N}$} & \multirow[t]{2}{*}{ EB } & \multirow[t]{2}{*}{ df } & \multirow[t]{2}{*}{$(\mathrm{Q})$} & \multirow{2}{*}{$\begin{array}{l}\text { Standart } \\
\text { Hata }\end{array}$} & \multirow[t]{2}{*}{$\mathbf{Z}$} & \multirow[t]{2}{*}{$\mathbf{p}$} & \multirow[t]{2}{*}{$\mathbf{I}^{2}$} & \multicolumn{2}{|c|}{$\begin{array}{c}\text { Etki Büyüklüğg̈ü İçin \%95'lik } \\
\text { Güven Aralığı }\end{array}$} \\
\hline & & & & & & & & & Alt sınır & Üst sınır \\
\hline SEM & 24 & ,883 & 23 & 427,54 & ,055 & 16,11 &, 00 & 94,62 & ,775 & ,990 \\
\hline REM & 24 & 1,521 & & & ,243 & 6,248 &, 00 & & 1,044 & 1,998 \\
\hline
\end{tabular}

Araştırmaya dâhil edilen öğrenilen bilgilerin kalıcılığına ait çalışmaların homojenlik değeri sabit etkiler modeline göre $\mathrm{Q}=427,54$ ve $\mathrm{p}=, 00$ olarak bulunmuştur. $\mathrm{P}$ değerinin $\% 95$ anlamlılık düzeyine göre, 05 'den küçük olması bağımsız değişkenler arasında istatistiksel olarak anlamlı bir farkın olduğunu ortaya koymaktadır. Bu nedenle öğrenilen bilgilerin kalıcılığına ait çalışmaların etki büyüklüğü değerlerinin heterojen yapıda olduğu görülmektedir. 
Rastgele etkiler modeline (REM) göre yapılan analiz sonucunda ortalama etki büyüklügü değeri ,243 standart hata ile 1,521 olarak bulunmuştur. Bu etki Thalheimer ve Cook (2002) sınıflandırmasına göre mükemmel düzeyde bir etkiyle sahiptir.

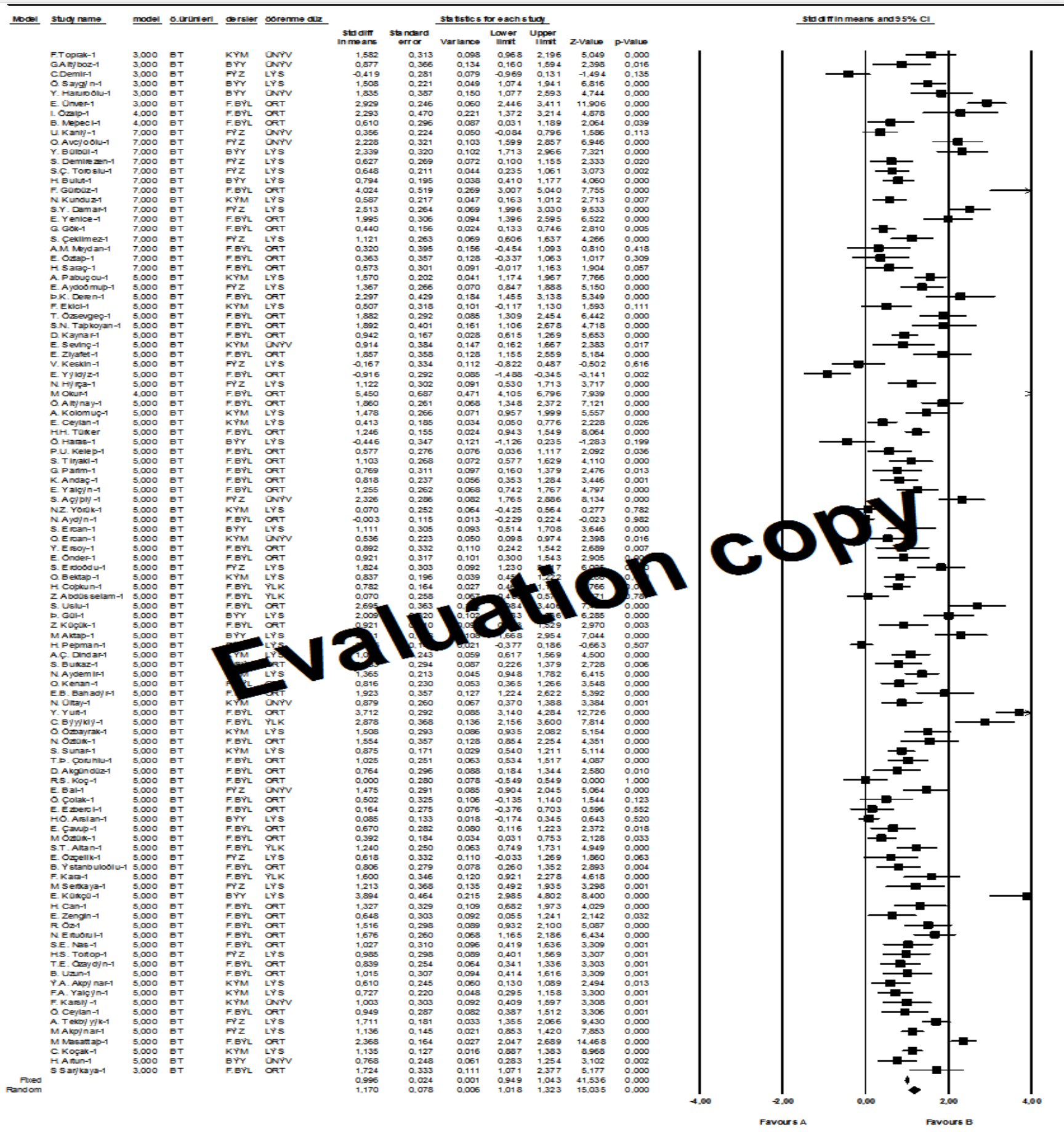

Şekil-1 Araştırmaya dahil edilen akademik başarıya etki çalışmalarına ait orman grafiğgi

Öğrenilen bilgilerin kalıcılı̆̆ı çalışmalarına ait etki büyüklükleri incelendiğinde en küçük etki büyüklüğü değerinin -1,783 (Demirezen, 2010), en yüksek etki büyüklüğü değerinin ise 6,493 (Gürbüz, 2012) etki alanında olduğu belirlenmiştir. Çalışmaların etki büyüklüklerine bakıldığında 24 etki büyüklüğünün 22'si pozitif ve 2'si negatif etki değerine sahiptir.

Birincil çalışmalarda yer alan derse yönelik tutuma ait etki büyüklüğü sabit etkiler modeline (SEM) ve rastgele etkiler modeline (REM) göre değerleri Tablo 5'de, bu değerlerin dağılımını gösteren orman grafiği ise Şekil 3 'de gösterilmiştir. 
Araştırmaya dâhil edilen derse olan tutuma ait çalışmaların homojenlik değeri sabit etkiler modeline göre Q= 404,965 ve $\mathrm{p}=, 00$ olarak bulunmuştur. $\mathrm{P}$ değerinin \% 95 anlamlılık düzeyine göre, 05 'den küçük olması bağımsız değişkenler arasında istatistiksel olarak anlamlı bir farkın olduğunu ortaya koymaktadır. Bu nedenle derse yönelik tutuma ait çalışmaların etki büyüklüğü değerlerinin heterojen yapıda olduğu görülmektedir. Rastgele etkiler modeline (REM) göre yapılan analiz sonucunda ortalama etki büyüklüğü değeri ,075 standart hata ile ,502 olarak bulunmuştur. Bu etki Thalheimer ve Cook (2002) sinıflandırmasına göre orta düzeyde bir etkiyle sahiptir.

Illodel Stuty name model öurinleri dersler öbremme dizz

Stafisfics for each stude

Sid diff Standard Lower Upper

inmeans error Variance limit limit $Z \cdot V$ alue p.Value

\begin{tabular}{|c|c|c|c|c|}
\hline F.Top rk-2 & 3,000 & KT & KYM & ONP \\
\hline Y. Hanund IJ-2 & 3,000 & $k T$ & BYY & $\mathrm{ONY}$ \\
\hline L. Caza|p-2 & 4,000 & $K T$ & FBÝL & ORT \\
\hline S. Demlezen-2 & 7,000 & $k T$ & $\mathrm{FYZ}$ & LYYs \\
\hline F. Garbizz & 7,000 & $k T$ & FBYYL & ORT \\
\hline E. Yenilo:-2 & 7,000 & KT & FBYYL & ORT \\
\hline H Saraç-2 & 7,000 & KT & FBYL & ORT \\
\hline S.N Tapkoyan-2 & 5,000 & KT & FBYL & ORT \\
\hline M ONF2 & 4,000 & KT & FBÝL & ORT \\
\hline A. Kolomuç-2 & 5,000 & KT & KYM & LYेs \\
\hline K. Andaç-2 & 5,000 & KT & FBÝl & ORT \\
\hline D. $\mathbf{G} \|=2$ & 5,000 & KT & BYY & LYेs \\
\hline H Pepman-2 & 5,000 & KT & $F Y Z$ & LYेs \\
\hline N Ajoemir.2 & 5,000 & KT & KYM & LYYs \\
\hline O. Kenaา-2 & 5,000 & KT & FBÝL & ORT \\
\hline N Otay-2 & 5,000 & KT & KYM & ONY \\
\hline C. Blyjkll 2 & 5,000 & KT & FBYYL & $y$ \\
\hline s. Sงาar2 & 5,000 & KT & KYM & LỲs \\
\hline RS. $K O C$ - 2 & 5,000 & KT & FBÝl & ORT \\
\hline M Ctoti-2 & 5,000 & KT & FBYYL & ORT \\
\hline F. Кara-2 & 5,000 & KT & FBÝL & . \\
\hline E. ㄱangh-2 & 5,000 & KT & FBYYL & ORT \\
\hline T. Cosengeç2 & 5,000 & KT & FBYYL & ORT \\
\hline H Atun-2 & 5,000 & KT & BYYY & ONY \\
\hline
\end{tabular}

\begin{tabular}{|c|c|c|c|c|c|c|}
\hline 376 & 0,304 & 0,093 & 0,779 & 1,972 & 4,522 & 000 \\
\hline 47 & 0,364 & 0,133 & 0,733 & 2,162 & 3,971 & \\
\hline & 0,392 & 0,153 & 0,330 & 1,866 & 2,803 & \\
\hline & 0,311 & 0,097 & $-2,402$ & $-1,183$ & $-5,766$ & \\
\hline & 0,747 & 0,558 & 5,030 & 7,957 & 8,694 & \\
\hline & 0.295 & 0,087 & 1,196 & 2352 & 6,011 & \\
\hline & 0,399 & 0,159 & 1,796 & 3,360 & 6,451 & \\
\hline & 0,501 & 0.251 & 2,195 & 4,161 & 6,338 & \\
\hline & 0,686 & 0,471 & 4,101 & 6,790 & 7,937 & \\
\hline & 0,306 & 0,094 & 1,741 & 41 & 7,651 & \\
\hline 10 & 0.232 & 0,054 & 0,050 & 64 & 2,199 & \\
\hline (2) & 0,409 & 0,168 & 2,625 & 230 & 8,374 & \\
\hline II & 0,144 & 0,021 & $-0,459$ & 0,105 & $-1,228$ & \\
\hline & 0.230 & 0,053 & 1,423 & 324 & 8,151 & \\
\hline & 0,225 & 0,051 & 120 & 003 & 2,494 & \\
\hline & 0.259 & 0,067 & 0,344 & 1,360 & 3,287 & \\
\hline 20 & 0,413 & 0,170 & 2,719 & 37 & 8,547 & \\
\hline & 0,166 & 0,028 & 0,185 & 0,836 & 3,071 & \\
\hline o & 0.280 & 0,078 & $-0,549$ & 349 & 0,000 & \\
\hline & 0,187 & 0,035 & 0.232 & 964 & 3,205 & \\
\hline  & 0 & 0,111 & 0.671 & 5 & 3,975 & \\
\hline 4 & 0,304 & 0,093 & 8 & 310 & 2,349 & \\
\hline & 0.254 & 0,054 & 0,341 & 1,336 & 3,303 & \\
\hline & 0,248 & 0,061 & 0,283 & 1,254 & 3,102 & \\
\hline & 0,055 & 0,003 & 0,775 & 0990 & 16,109 & \\
\hline & 0.243 & 0,059 & 1,044 & 1998 & 6,248 & \\
\hline
\end{tabular}

Std diff inmeans and $95 \%$ Cl

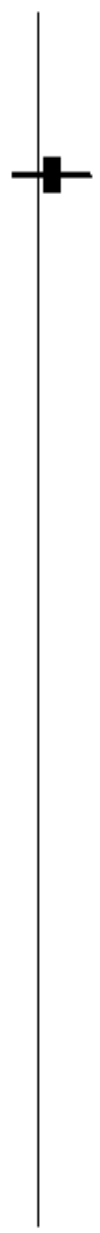

2,200

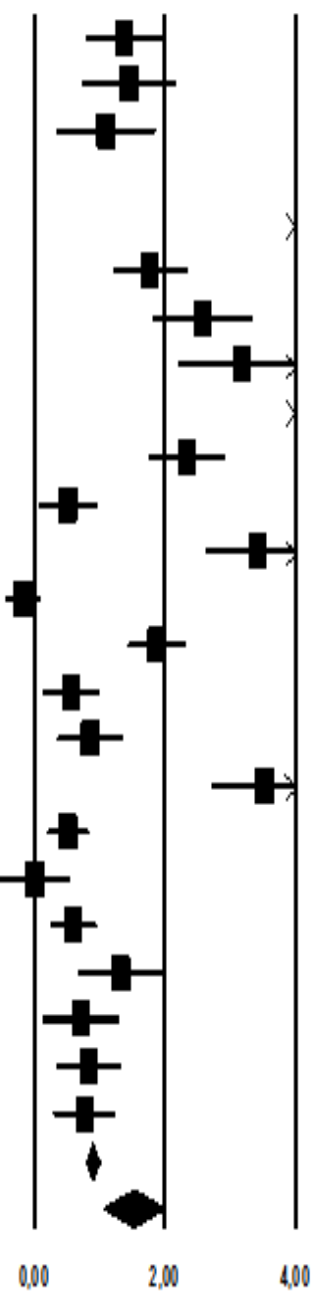

Favours A

Favours B

Şekil-2 Araştırmaya dahil edilen kalıcılık etki çalışmalarına ait orman grafiği

Tablo 5. Çalışmaların Tutum Etki Büyüklüklerine Ait Bulgular

\begin{tabular}{|c|c|c|c|c|c|c|c|c|c|c|}
\hline \multirow[t]{2}{*}{ Model } & \multirow[t]{2}{*}{$\mathbf{N}$} & \multirow[t]{2}{*}{ EB } & \multirow[t]{2}{*}{ df } & \multirow[t]{2}{*}{$(\mathrm{Q})$} & \multirow{2}{*}{$\begin{array}{l}\text { Standart } \\
\text { Hata }\end{array}$} & \multirow[t]{2}{*}{$\mathbf{Z}$} & \multirow[t]{2}{*}{$\mathbf{P}$} & \multirow[t]{2}{*}{$\mathbf{I}^{2}$} & \multicolumn{2}{|c|}{$\begin{array}{c}\text { Etki Büyüklüğü İçin \%95'lik } \\
\text { Güven Aralığı }\end{array}$} \\
\hline & & & & & & & & & Alt sinir & Üst sınır \\
\hline SEM & 64 & ,460 & 63 & 404,96 & ,029 & 15,950 & ,00 & 84,44 & ,404 & ,517 \\
\hline REM & 64 & ,502 & & & ,075 & 6,685 & ,00 & & 355 & ,649 \\
\hline
\end{tabular}


Derse yönelik tutum çalışmaları incelendiğinde en küçük etki büyüklüğü değerinin -,965 (Bahadır, 2012), en yüksek etki büyüklüğü değerinin ise 3,881 (Yalçın, 2010) etki alanında olduğu belirlenmiştir. Çalışmaların etki büyüklüklerine bakıldığında 64 etki büyüklügünün 55'i pozitif ve 9'u ise negatif etki değerine sahiptir.

Birincil çalışmalarda yer alan bilimsel süreç becerileri testine ait etki büyüklüğü sabit etkiler modeline (SEM) ve rastgele etkiler modeline (REM) göre değerleri Tablo 6'da, bu değerlerin dağılımını gösteren orman grafiği ise Şekil 4'de gösterilmiştir.

Araştırmaya dâhil edilen derse olan tutuma ait çalışmaların homojenlik değeri sabit etkiler modeline göre Q= 328,06 ve $\mathrm{p}=, 00$ olarak bulunmuştur. $\mathrm{P}$ değerinin $\% 95$ anlamlılık düzeyine göre, 05 'den küçük olması bağımsız değişkenler arasında istatistiksel olarak anlamlı bir farkın olduğunu ortaya koymaktadır. Bu nedenle derse yönelik tutuma ait çalışmaların etki büyüklüğü değerlerinin heterojen yapıda olduğu görülmektedir. Rastgele etkiler modeline (REM) göre yapılan analiz sonucunda ortalama etki büyüklüğü değeri ,133 standart hata ile ,899 olarak bulunmuştur. Bu etki Thalheimer ve Cook (2002) sınıflandırmasına göre geniş düzeyde bir etkiyle sahiptir.

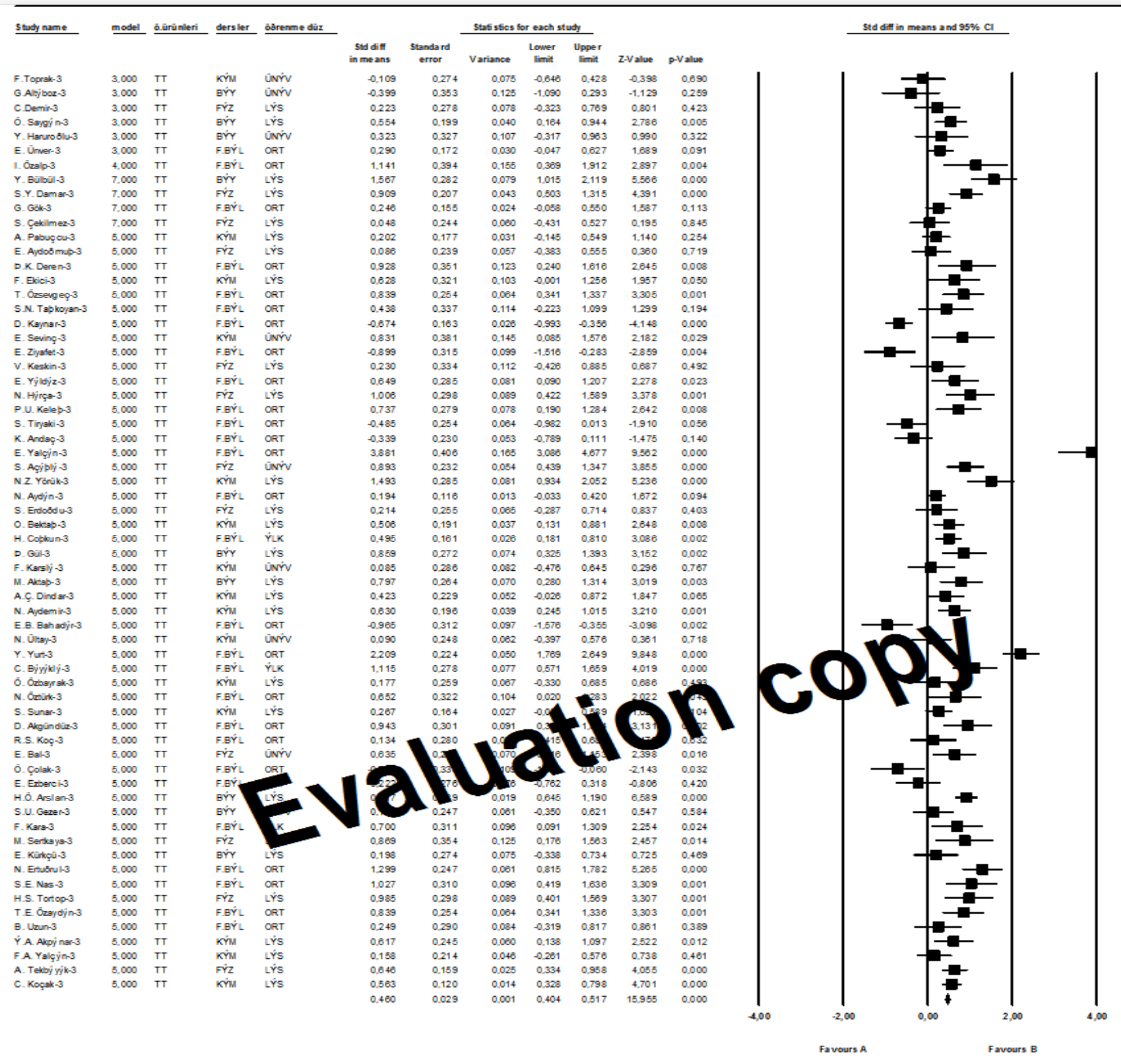

Şekil-3 Araştırmaya dahil edilen tutum etki çalışmalarına ait orman grafiği 
Bilimsel süreç becerilerine yönelik çalışmalara ait etki büyüklükleri incelendiğinde en küçük etki büyüklüğü değerinin -1,441 (Aydemir, 2012), en yüksek etki büyüklüğü değerinin ise 3,134 (Bıyıklı, 2013) etki alanında olduğu belirlenmiştir. Çalışmaların etki büyüklüklerine bakıldığında 33 etki büyüklüğünün 51'i pozitif ve 2'si ise negatif etki değerine sahiptir.

Meta-analiz çalışmalarında dikkat edilmesi gereken konulardan bir tanesi yayın yanlılı̆̆ıdır. Orwin yöntemiyle yapılan analizler sonucunda elde edilen ,967 etki büyüklüğü değerini 0 (sıfir) etki büyüklüğü değerine düşürmek için etki büyüklükleri 0 (sıfır) olan gerekli çalışma sayısının 11051 olduğu belirlenmiştir. Bu çok yüksek bir sayıdır ve yayın yanlılığının düşük olduğunu göstermektedir. Bunun yanında yayın yanlılığının olup olmadığı Şekil 5'de verilen Funnel Plot ile de yorumlanabilir.

Huni grafiğinde yayın yanlılı̆̆ı olması durumunda etki büyüklükleri asimetrik bir şekilde yer alacaklardır. Yayın yanlılığı olmaması durumda ise simetrik dağılım gösterirler. Şekil-4'de görüldüğü gibi çalışmalardan elde edilen huni neredeyse simetrik bir yapı göstermektedir. Buna göre çalışmada yanlılığın olmadığı söylenebilir.

Meta-analizde elde edilen etki büyüklükleri çalışmaların çeşitli karakteristiklerine göre alt gruplara ayrılmış ve analiz sonuçları Tablo 6'da gösterilmiştir.

Tablo 6. Çalışmaların Bilimsel Süreç Becerileri Etki Büyüklüklerine Ait Bulgular

\begin{tabular}{|c|c|c|c|c|c|c|c|c|c|c|}
\hline \multirow[t]{2}{*}{ Model } & \multirow[t]{2}{*}{$\mathbf{N}$} & \multirow[t]{2}{*}{ EB } & \multirow[t]{2}{*}{ df } & \multirow[t]{2}{*}{$(\mathbf{Q})$} & \multirow{2}{*}{$\begin{array}{l}\text { Standart } \\
\text { Hata }\end{array}$} & \multirow[t]{2}{*}{$\mathbf{Z}$} & \multirow[t]{2}{*}{$\mathbf{p}$} & \multirow[t]{2}{*}{$\mathbf{I}^{2}$} & \multicolumn{2}{|c|}{$\begin{array}{c}\text { Etki Büyüklüğü İçin \%95'lik } \\
\text { Güven Aralığı }\end{array}$} \\
\hline & & & & & & & & & Alt sinır & Üst sınır \\
\hline SEM & 33 & ,816 & 32 & 328,06 & ,041 & 20,040 & ,00 & 90,24 & ,736 & ,895 \\
\hline REM & 33 & ,899 & & & ,133 & 6,747 & ,00 & & ,638 & 1,161 \\
\hline
\end{tabular}

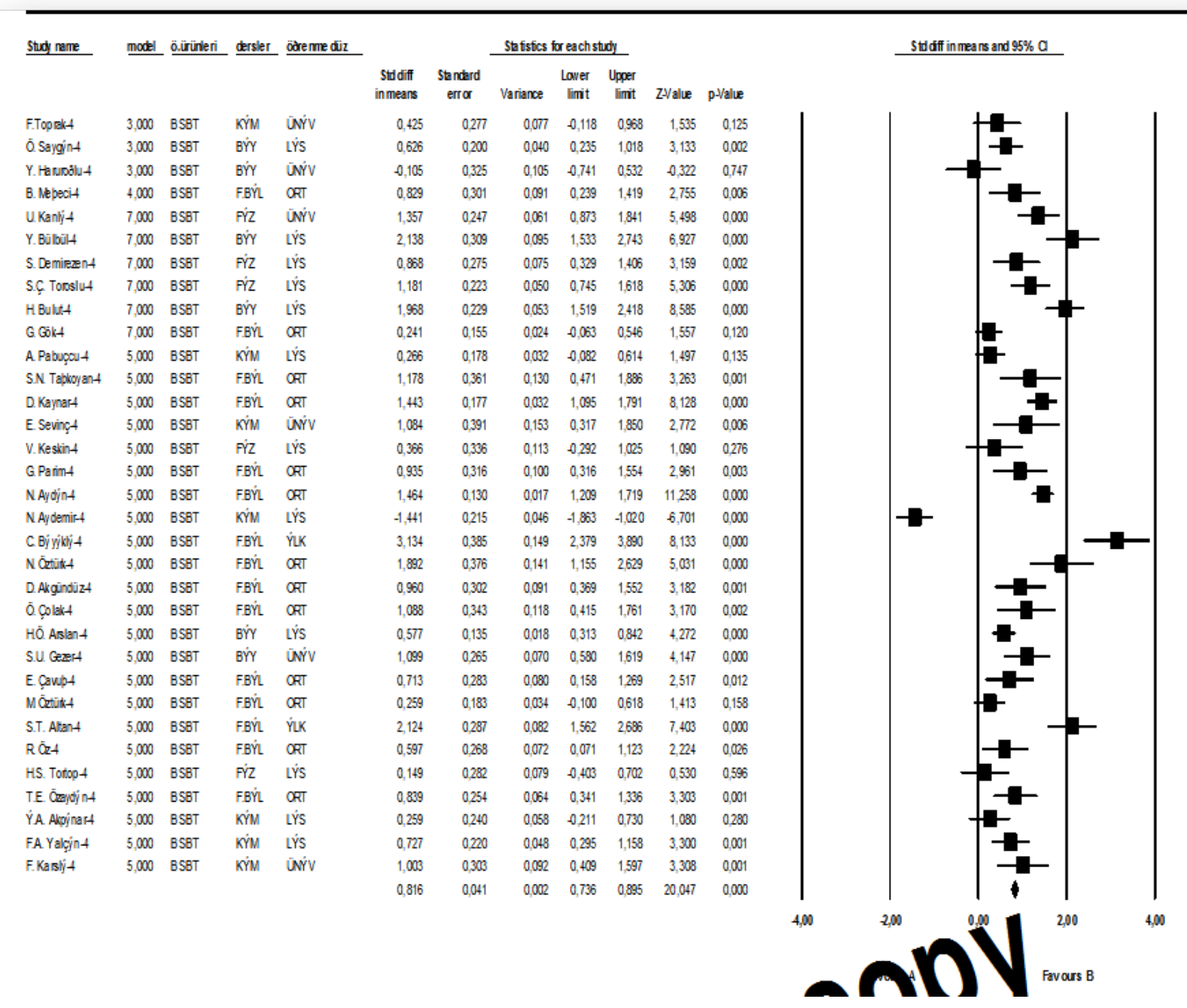


Şekil-4 Araştırmaya dahil edilen bilimsel süreç becerileri etki çalışmalarına ait orman grafiği

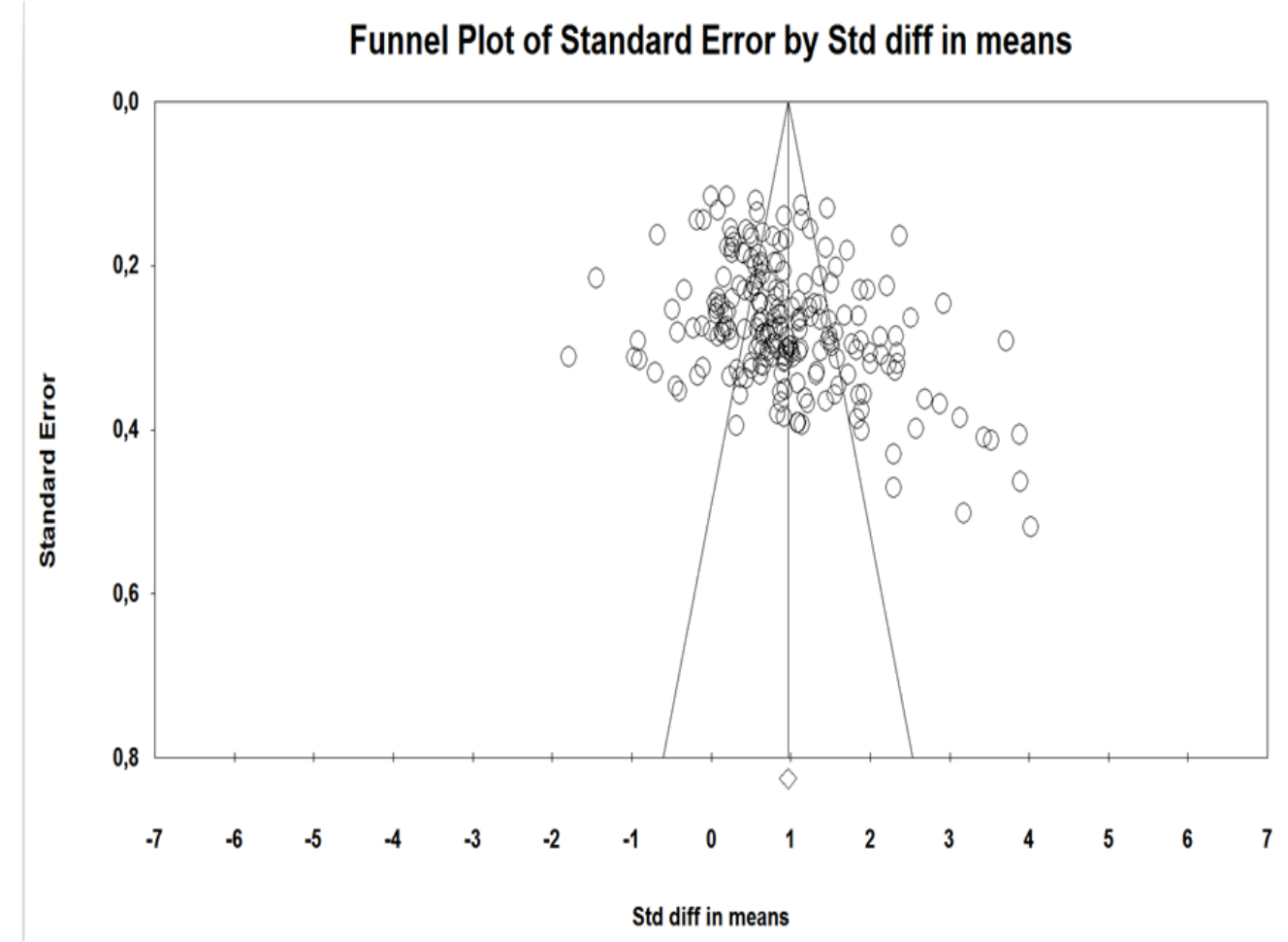

Şekil-5 Araştırmaya dahil edilen çalışmalara ait huni grafiği

Tablo 7. Çalışma Karakteristiklerine Göre İstatistiksel Analizler

\begin{tabular}{|c|c|c|c|c|c|c|c|}
\hline \multirow{2}{*}{$\begin{array}{c}\text { Çalışma } \\
\text { Karakteristikleri }\end{array}$} & \multirow{2}{*}{$\begin{array}{c}\text { Gruplar arası } \\
\text { Homojenlik (Qв) }\end{array}$} & \multirow{2}{*}{$\mathbf{p}$} & \multirow{2}{*}{$\mathbf{N}$} & \multirow{2}{*}{ ES } & \multicolumn{2}{|c|}{ ES (\%95 CI) } & \multirow{2}{*}{$\begin{array}{c}\text { Standart Hata } \\
\text { (SE) }\end{array}$} \\
\hline & & & & & Alt & Üst & \\
\hline $\begin{array}{c}\text { Öğrenme } \\
\text { Ürünü }\end{array}$ & 46,091 &, 00 & & & & & \\
\hline Başarı & & & 106 & 1,170 & ,99 & 1,30 & ,078 \\
\hline Kalıcılik & & & 24 & 1,521 & 1,00 & 1,91 & ,243 \\
\hline Tutum & & & 64 &, 502 &, 16 & ,93 & 075 \\
\hline Bilimsel Süreç Becerileri & & & 33 & ,899 & ,63 & 1,14 & ,133 \\
\hline Kullanılan Model & 8,868 & ,031 & & & & & \\
\hline $3 E$ & & & 18 & ,812 & ,40 & 1,22 & 209 \\
\hline $4 \mathrm{E}$ & & & 7 & 2,289 & 1,13 & 3,44 & ,588 \\
\hline $5 \mathrm{E}$ & & & 173 & 903 & ,78 & 1,01 & ,058 \\
\hline $7 \mathrm{E}$ & & & 29 & 1,238 & ,89 & 1,58 & 178 \\
\hline Lisansüstü Tez & 3,662 & ,056 & & & & & \\
\hline Doktora & & & 121 & 869 & ,74 & ,99 & ,066 \\
\hline Y.Lisans & & & 106 & 1,081 & ,90 & 1,25 & ,089 \\
\hline Fen Alanı & 13,668 & ,003 & & & & & \\
\hline Biyoloji & & & 30 & 1,099 & ,80 & 1,36 & ,146 \\
\hline Fen Bil... & & & 113 & 1,118 & ,92 & 1,26 & ,086 \\
\hline Fizik & & & 38 & ,769 &, 51 & 1,00 & 127 \\
\hline Kimya & & & 46 & ,715 & ,53 & ,87 & ,087 \\
\hline $\begin{array}{c}\text { Öğrenim } \\
\text { Düzeyi }\end{array}$ & 9,568 & ,023 & & & & & \\
\hline İlkokul & & & 12 & 1,540 & ,99 & 2,04 & 272 \\
\hline Ortaokul & & & 101 & 1,068 & ,86 & 1,22 & ,091 \\
\hline Lise & & & 83 & ,826 & ,66 & ,97 & 079 \\
\hline Üniversite & & & 31 & ,846 & ,61 & 1,05 & 113 \\
\hline
\end{tabular}


$\mathrm{p}<.05$

Yapılan alt grup analizlerde öğrenme ürünleri $\left(\mathrm{Q}_{\mathrm{B}}=46,091, \mathrm{p}<, 05\right)$, kullanılan öğrenme halkas1 modelleri $\left(\mathrm{Q}_{\mathrm{B}}=8,868, \mathrm{p}<, 05\right)$, çalışmaların yapıldı ̆̆ Fen alanı $\left(\mathrm{Q}_{\mathrm{B}}=13,668, \mathrm{p}<, 05\right)$ ve öğrenme düzeyi $\left(\mathrm{Q}_{\mathrm{B}}=9,568, \mathrm{p}<, 05\right)$ alt boyutlarında istatistiksel olarak anlamlı fark vardır. Bu fark öğrenme ürünlerinde öğrenilen bilgilerin kalıcılığ öğrenme halkası modelleri alanında 4E Modeli, Fen alanında Fen bilimleri ve öğrenim düzeyi alanında ise ilkokul öğrencileri lehinedir. Yani yapılandırmacı yaklaşım öğrenme halkası modellerinin, işlenen derslerde öğrenilen bilgilerin kalıcı olmasında, 4E öğrenme modelinin kullanılmasında, Fen bilimler derslerinde ve ilkokul öğrencileri üzerinde daha etkili olduğu görülmektedir. Yapılan alt grup analizleri devamında yapılan araştırmaların lisansüstü türleri $\left(\mathrm{Q}_{\mathrm{B}}=3,662, \mathrm{p}>, 05\right)$ alt boyutunda ise istatistiksel olarak anlamlı fark bulunmamıştır. Diğer bir ifade ile yapılandırmacı yaklaşım öğrenme halkası modeli kullanılarak işlenen derslerde öğrencilerin, doktora ya da yüksek lisans olarak yayımlanan araştırmaların etki büyüklükleri arasında istatistiksel olarak anlamlı düzeyde bir fark yoktur.

\section{Tartışma ve Sonuç}

Araştırmada pozitif yönde ,967 ile geniş düzeyinde deney grupları lehine olan bir sonuca ulaşılmıştır. Ulaşılan bu sonuç, alan yazında Fen öğretimi araştırmaları kapsamında ulusal alanda yapılan meta analiz çalışmalarından elde edilen (Aktamış \& Özden, 2016; Ayaz, 2015b; Ayaz \& Söylemez, 2015; Ayaz \& Şekerci, 2015; Bozdemir, Çevik, Altunoğlu, \& Kurnaz, 2017; Balta \& Saraç, 2016; Saraç, 2017; Ural \& Bümen, 2016) sonuçlar ile örtüşmektedir. Dinçer ve Güçlü (2013) ile Yeşilyurt'un (2011) çalışmalarında Fen öğretiminde öğrenme halkası temelli hazırlanan bilgisayar destekli materyallerin başarıya etkisi mükemmel düzeyde; Ayaz (2015a) ile Öztürk ve Karakuş’un (2016) çalışmalarında Fen öğretiminde yapılandırmacı yaklaşım öğrenme halkası modellerinin kullanılan derse olan tutuma etkisi ise küçük düzeydedir. Bu durumda Dinçer ve Güçlü (2013), Yeşilyurt (2011), Öztürk ve Karakuş (2016) ve Ayaz'ın (2015a) ulaştı̆̆ sonuçlar ile bu araştırmadan elde edilen sonuç örtüşmemektedir.

Araştırmadan elde edilen meta analiz yöntemi sonuçlarına çalışmaların öğrenme ürünleri alanına göre bakıldığında, Fen öğretimi sürecinde yapılandırmacı yaklaşım öğrenme halkası modelleri kullanılarak yapılan çalışmalarda öğrenme ürünleri etki büyüklükleri arasında istatistiksel olarak anlamlı bir farkın olduğu ortaya çıkmıştır. İncelenen çalışmaların öğrenme ürünleri alanına göre değerlendirilmesinde en yüksek etki büyüklügü değerinin öğrenilen bilgilerin kalıcılığında mükemmel düzeyde ve devamında akademik başarı alanında $(\mathrm{EB}=1,170)$ geniş düzeyde olduğu ortaya çıkmıştır. Öğrenme ürünleri etki büyüklükleri arasında en küçük etki büyüklüğü değerinin derse olan tutuma yönelik $(\mathrm{EB}=, 502)$ ve devamında bilimsel süreç becerileri alanında $(\mathrm{EB}=, 899)$ ile orta düzeyde olduğu görülmektedir. Öğrenme ürünleri arasındaki anlamlı fark öğrenilen bilgilerin kalıcılığı lehinedir.

Araştırmadan elde edilen sonuçlar öğrenme ürünleri alanında akademik başarı düzeyinde incelendiğinde, Fen öğretimi sürecinde yapılandırmacı yaklaşım öğrenme halkası modelleri kullanımının öğrencilerin akademik başarılarına olan etkisi 1,170 ile çok geniş düzeyde bir etkiye sahiptir. Alan yazında Fen öğretiminde Astronomi araştırmaları kapsamında Bozdemir, Çevik, Altunoğlu, \& Kurnaz'ın (2017) yaptıkları meta analiz çalışmasının sonucunda öğrencilerin akademik başarılarına olan etki değeri ,82 ile geniş düzeyde olduğu; Saraç'ın (2017) yaptığ1 çalışmada eğitim-öğretim sürecinde Akıllı tahta kullanımının öğrencilerin akademik başarısına olan etki büyüklüğü ,809 ile geniş düzeyde olduğu; Aktamış ve Özden'in (2016) yaptıkları araştırmada Fen öğretiminde araştırmasorgulamaya dayalı öğrenmenin öğrencilerin akademik başarısına olan etki büyüklügü 1,029 ile geniş düzeyde olduğu; eğitim-öğretim araştırmaları kapsamında ulusal alanda Balta ve Saraç'ın (2016) yaptıkları çalışmada 7E öğrenme modeli kullanımının öğrencilerin akademik başarılarına olan etkisinin 1,240 ile çok geniş düzeyde olduğu; Ural ve Bümen'in (2016) yaptıkları çalışmada Fen öğretiminde yapılandırmacı öğrenme yaklaşımının öğrencilerin akademik başarılarına olan etkisini 1,003 ile geniş düzeyde olduğunu; Ayaz'ın (2015b) yaptığı çalışmada Fen öğretiminde Probleme dayalı öğrenme modelinin öğrencilerin akademik başarısına olan etki büyüklüğü 1,206 ile çok geniş düzeyde olduğu; Ayaz ve Şekerci'nin (2015) yaptıkları çalışmada yapılandırmacı öğrenme yaklaşımının öğrencilerin akademik başarılarına olan etkisinin 1,156 ile çok geniş düzeyde olduğu tespit edilmiştir. Buna göre, fen öğretimi sürecinde yapılandırmacı yaklaşım öğrenme halkası modelleri kullanımının öğrencilerin akademik başarısına etkisi meta analiz çalı̧̧masından elde edilen sonuç ile alan yazında benzer alanda (Aktamış \& Özden, 2016; Ayaz, 2015b; Ayaz \& Şekerci, 2015; Balta \& Saraç, 2016; Bozdemir, Çevik, Altunoğlu, \& Kurnaz, 2017; Saraç, 2017; Ural \& Bümen, 2016) yapılan meta analiz çalışmalarından elde edilen sonuçlar benzerlik göstermektedir. Öztürk ve Karakuş (2016) yaptıkları çalışmada Fen öğretiminde işbirliğine dayalı öğrenmenin öğrencilerin akademik başarısına olan etki 
büyüklüğü değerini orta düzeyde olduğunu, Dinçer ve Güçlü (2013) ile Yeşilyurt'un (2011) çalışmalarında Fen öğretiminde öğrenme halkası temelli hazırlanan bilgisayar destekli materyallerin başarıya etkisi mükemmel düzeyde olduğunu tespit etmiş̧lerdir. Buna göre, Fen öğretimi sürecinde yapılandırmacı yaklaşım öğrenme halkası modelleri kullanımının öğrencilerin akademik başarısına etkisi meta analiz çalışmasından elde edilen sonuç ile alan yazında benzer alanda (Dinçer \& Güçlü, 2013; Öztürk \& Karakuş, 2016; Yeşilyurt, 2011) yapılan meta analiz çalışmalarından elde edilen sonuçlar ise örtüşmemektedir.

Araştırmadan elde edilen sonuçlar öğrenme ürünleri alanında öğrenilen bilgilerin akılda kalıcıllı̆ga etkisi düzeyinde incelendiğinde, Fen öğretimi sürecinde yapılandırmacı yaklaşım öğrenme halkası modelleri kullanımının kalıcılığa olan etkisi 1,521 ile mükemmel düzeyde bir etkiye sahiptir. Alan yazında eğitim-öğretim araştırmaları kapsamında, Saraç (2017) yaptığı çalışmada akıllı tahta kullanımının öğrenilen bilgilerin akılda kalıcılığa olan etkisinin 1,009 ile geniş düzeyde olduğu tespit edilmiştir. Buna göre, Fen öğretimi sürecinde yapılandırmacı yaklaşım öğrenme halkası modelleri kullanımının öğrenilen bilgilerin kalıcılığa etkisi meta analiz çalışmasından elde edilen sonuç ile alan yazında Saraç'ın (2017) yaptığı meta analiz çalışmasından elde edilen sonuç kısmen benzerlik göstermektedir.

Araştırmadan elde edilen sonuçlar öğrenme ürünleri alanında derse olan tutum düzeyinde incelendiğinde, Fen öğretimi sürecinde yapılandırmacı yaklaşım öğrenme halkası modelleri kullanımının öğrencilerin derse olan tutumuna etkisi ,502 ile orta düzeyde bir etkiye sahiptir. Alan yazında eğitim-öğretim araştırmaları kapsamında ulusal alanda Ayaz ve Söylemez'in (2015) yaptıkları çalışmada Fen öğretiminde proje temelli öğrenme modelinin öğrencilerin derse olan tutuma etkisinin ,997 ile geniş düzeyde olduğu ve Saraç (2017) yaptığı çalışmada akıllı tahta kullanımının öğrencilerin derse olan tutuma etkisinin ,807 ile geniş düzeyde olduğu tespit edilmiştir. Buna göre, Fen öğretimi sürecinde yapılandırmacı yaklaşım öğrenme halkası modelleri kullanımının öğrencilerin derse olan tutuma etkisi meta analiz çalışmasından elde edilen sonuç ile alan yazında benzer alanda (Ayaz \& Söylemez, 2015; Saraç, 2017) yapılan meta analiz çalışmalarından elde edilen sonuçlar kısmen benzerlik göstermektedir. Aktamış ve Özden'in (2016) yaptıkları çalışmada Fen öğretiminde araştırma-sorgulamaya dayalı öğretimin öğrencilerin derse olan tutuma etkisini ,530 ile orta düzeyde olduğu, Ural ve Bümen'in (2016) yaptıkları çalışmada Fen öğretiminde yapılandırmacı öğrenme yaklaşımının öğrencilerin derse olan tutuma etkisini ,743 ile orta düzeyde olduğu ve Ayaz ve Şekerci'nin (2015) yaptıkları çalışmada yapılandırmacı öğrenme yaklaşımının öğrencilerin derse olan tutuma etkisinin ,755 ile orta düzeyde olduğu tespit edilmiştir. Bu durumda Aktamış ve Özden (2016), Ural ve Bümen (2016) ve Ayaz ve Şekerci'nin (2015) ulaştığı sonuçlar ile bu araştırmadan elde edilen Fen öğretimi sürecinde yapılandırmacı yaklaşım öğrenme halkası modelleri kullanımının derse olan tutuma yönelik etkisinin sonucu benzerlik göstermektedir. Ayrıca, Öztürk ve Karakuş (2016) yaptıkları çalışmada Fen öğretiminde işbirliğine dayalı öğrenmenin öğrencilerin derse olan tutuma yönelik etki büyüklüğü değerini ,210 ile küçük düzeyde olduğu, Ayaz'ın (2015a) yaptığı çalışmada 5E öğrenme modelinin derse olan tutuma yönelik etkisini ,370 ile küçük düzeyde olduğunu tespit etmişlerdir. Buna göre, Öztürk ve Karakuş (2016) ve Ayaz'ın (2015) ulaştığı sonuç ile bu araştırmadan elde edilen Fen öğretimi sürecinde yapılandırmacı yaklaşım öğrenme halkası modelleri kullanımının derse olan tutuma yönelik etkisinin sonucu örtüşmemektedir.

Araştırmadan elde edilen sonuçlar öğrenme ürünleri alanında bilimsel süreç becerilerine yönelik etkisi düzeyinde incelendiğinde, Fen öğretimi sürecinde yapılandırmacı yaklaşım öğrenme halkası modelleri kullanımının bilimsel süreç becerilerine olan etkisi ,899 ile geniş düzeyde bir etkiye sahiptir. Alan yazında eğitim-öğretim araştırmaları kapsamında, Aktamış ve Özden'in (2016) yaptıkları çalışmada Fen öğretiminde araştırma-sorgulamaya dayalı öğretimin öğrencilerin bilimsel süreç becerilerine yönelik etkisini ,742 ile orta düzeyde olduğu tespit edilmiştir. Buna göre, Fen öğretimi sürecinde yapılandırmacı yaklaşım öğrenme halkası modelleri kullanımının bilimsel süreç becerilerine yönelik etkisi meta analiz çalışmasından elde edilen sonuç ile alan yazında Aktamış ve Özden'in (2016) yaptığı meta analiz çalışmasından elde edilen sonuç kısmen benzerlik göstermektedir.

Araştırmadan elde edilen meta analiz yöntemi sonuçlarına çalışmalarda kullanılan yapılandırmacı yaklaşım öğrenme halkası modelleri türüne göre bakıldığında, Fen öğretimi sürecinde yapılandırmacı yaklaşım öğrenme halkası modelleri kullanılarak yapılan çalışmaların öğrenme ürünlerine etkisi ile kullanılan öğrenme halkası model türü arasında istatistiksel olarak anlamlı bir farkın olduğu ortaya çıkmıştır. Bu fark 4E öğrenme modeli lehinedir. İncelenen çalışmaların öğrenme halkası model türüne göre değerlendirilmesinde en yüksek etki büyüklüğü değerinin $4 \mathrm{E}$ Model'inde $(\mathrm{EB}=2,289)$ mükemmel düzeyde olduğu görülmektedir. Ayrıca, incelenen çalışmalarda 5E Modeli 
düzeyinde etki büyüklüğü değeri $(\mathrm{EB}=, 903)$ ile geniş düzeyde olduğu görülmektedir. Alan yazında eğitim-öğretim araştırmaları kapsamında, Ayaz (2015a) yaptığı çalışmada 5E öğrenme modelinin derse olan tutuma yönelik etkisini ,370 ile küçük düzeyde olduğunu tespit etmiştir. Buna göre Ayaz'ın (2015a) yapmış olduğu meta analiz çalışmasında $5 \mathrm{E}$ öğrenme modeli kullanarak elde edilen sonuç ile araştırmada 5E öğrenme modeli kullanımının öğrencilerin öğrenme ürünlerine etkisine göre elde edilen sonuç benzerlik göstermemektedir.

Araştırmadan elde edilen meta analiz yöntemi sonuçlarına çalışmaların lisansüstü tez türüne göre bakıldığında, Fen öğretimi sürecinde yapılandırmacı yaklaşım öğrenme halkası modelleri kullanılarak yapılan çalışmaların öğrenme ürünlerine etkisi ile lisansüstü tez türü arasında istatistiksel olarak anlamlı bir farkın olmadığ 1 ortaya çıkmıştır. İncelenen çalışmaların lisansüstü tez türüne göre değerlendirilmesinde en yüksek etki büyüklüğü değerinin yüksek lisans tezlerinde $(\mathrm{EB}=1,081)$ geniş düzeyde olduğu görülmektedir. Alan yazında eğitim-öğretim araştırmaları kapsamında lisansüstü tez türlerinde en yüksek etki büyüklüğü değerlerinin Balta ve Saraç'ın (2016) yaptıkları çalışmada 1,307 ile yüksek lisans tezi araştırmalarında olduğu görülmüştür. Buna göre Balta ve Saraç’1n (2016) yapmış oldukları meta analiz çalışmasında lisansüstü tez türlerine göre elde edilen sonuç ile araştırmada Fen öğretimi sürecinde yapılandırmacı yaklaşım öğrenme halkası modelleri kullanımının öğrencilerin öğrenme ürünlerine etkisinin lisansüstü tez türüne göre elde edilen sonuç benzerlik göstermektedir. Ayrıca Ayaz'ın (2015a) yaptığı çalışmada ,663, Ayaz'ın (2015b) yaptığı diğer çalışmasında 1,598, Öztürk ve Karakuş'un (2016) yaptığı çalışmada ,890 ve Saraç'ın (2017) yaptığ 1 çalışmada ,919 etki büyüklüğü değeri ile doktora tezi çalışmalarında olduğu görülmüştür. Bu durumda Ayaz (2015a), Ayaz (2015b), Öztürk ve Karakuş (2016) ve Saraç'ın (2017) yapmış oldukları meta analiz çalışmalarında lisansüstü tez türlerine göre elde edilen sonuç ile araştırmada Fen öğretimi sürecinde yapılandırmacı yaklaşım öğrenme halkası modelleri kullanımının öğrencilerin öğrenme ürünlerine etkisinin lisansüstü tez türüne göre elde edilen sonuç benzerlik göstermemektedir.

Araştırmadan elde edilen meta analiz yöntemi sonuçlarına çalışmaların Fen alanına göre bakıldığında, Fen öğretimi sürecinde yapılandırmacı yaklaşım öğrenme halkası modelleri kullanılarak yapılan çalışmaların öğrenme ürünlerine etkisi ile Fen alanı arasında istatistiksel olarak anlamlı bir farkın olduğu ortaya çıkmıştır. Bu fark ilkokul ve ortaokul Fen bilimler dersi lehinedir. İncelenen çalışmaların Fen alanına göre değerlendirilmesinde en yüksek etki büyüklüğü değerinin Fen bilimler dersinde $(E B=1,118)$ çok geniş düzeyde olduğu görülmektedir. Alan yazında eğitim-öğretim araştırmaları kapsamında Dinçer ve Güçlü (2013) çalışmasında ders alanında en yüksek etki büyüklüğü değerlerinin 1,470 ile Fen Bilgisi dersinde olduğu görülmüştür. Bu durumda Dinçer ve Güçlü'nün (2013) yapmış olduğu meta analiz çalışmasında Fen alanına göre elde edilen sonuç ile araştırmada Fen öğretimi sürecinde yapılandırmacı yaklaşım öğrenme halkası modelleri kullanımının öğrencilerin öğrenme ürünlerine etkisinin Fen alanına göre elde edilen sonuç benzerlik göstermektedir. Ayrıca Ayaz'ın (2015a) yaptığı çalışmada ,939 ile Müzik dersinde, Ayaz'ın (2015b) yaptığı diğer çalışmasında 1,432 ile Kimya dersinde, Ayaz ve Söylemez’in (2015) yaptıkları çalışmada ,770 ile Biyoloji dersinde, Balta ve Saraç'ın (2016) yaptığı çalışmada 2,066 ile Kimya dersinde, Ural ve Bümen'in (2016) yaptı̆̆ çalışmada ,970 ile Biyoloji dersinde, Öztürk ve Karakuş'un (2016) yaptığ1 çalışmada ,852 ile Fizik dersinde ve Saraç'ın (2017) yaptığı çalışmada 1,324 ile diğer derslerde olduğu görülmüştür. Bu durumda Ayaz (2015a), Ayaz (2015b), Ayaz ve Söylemez (2015), Balta ve Saraç (2016), Ural ve Bümen (2016), Öztürk ve Karakuş (2016) ve Saraç (2017) yapmış oldukları meta analiz çalışmalarında ders alanına göre elde edilen sonuç ile araştırmada Fen öğretimi sürecinde yapılandırmacı yaklaşım öğrenme halkası modelleri kullanımının öğrencilerin öğrenme ürünlerine etkisinin Fen alanına göre elde edilen sonuç benzerlik göstermemektedir.

Araştırmadan elde edilen meta analiz yöntemi sonuçlarına çalışma gruplarının öğrenme düzeylerine göre bakıldığında, Fen öğretimi sürecinde yapılandırmacı yaklaşım öğrenme halkası modelleri kullanılarak yapılan çalışmaların öğrenme ürünlerine etkisi ile çalışma gruplarının öğrenme düzeyleri arasında istatistiksel olarak anlamlı bir farkın olduğu ortaya çıkmıştır. Bu fark İlkokul öğrencileri lehinedir. İncelenen çalışmaların çalışma grubu öğrenme düzeylerine göre değerlendirilmesinde en yüksek etki büyüklüğü değerinin İlkokul öğrencilerinde $(\mathrm{ES}=1,540)$ çok geniş düzeyde olduğu görülmektedir. Alan yazında eğitim-öğretim araştırmaları kapsamında Ayaz'ın (2015b) yaptı̆̆ 1 çalışmada çalışma grubunun öğrenim düzeyinin en yüksek etki değeri 1,727 ile ilkokul öğrencilerinde olduğu görülmüştür. Bu durumda Ayaz'ın (2015b) yapmış olduğu meta analiz çalışmasında çalışma grubunun öğrenme düzeyine göre elde edilen sonuç ile araştırmada Fen öğretimi sürecinde yapılandırmacı yaklaşım öğrenme halkası modelleri kullanımının öğrencilerin öğrenme ürünlerine etkisinin çalışma grubunun öğrenme düzeyine göre elde edilen sonuç benzerlik göstermektedir. Ayrıca Ayaz'ın (2015a) yaptığı çalışmada ,767 ile en büyük etki değeri 
Üniversite öğrencilerinde, Ayaz ve Söylemez’in (2015) yaptıkları çalışmada ,844 ile Ortaokul öğrencilerinde, Balta ve Saraç'ın (2016) yaptıkları çalışmada çalışma grubu öğrenim düzeyine göre en yüksek etki değeri 1,419 ile Lise öğrencilerinde, Saraç'ın (2017) yaptığı çalışmada 1,024 ile en yüksek etki değerinin Üniversite öğrencilerinde olduğu görülmüştür. Buna göre Ayaz (2015a), Ayaz ve Söylemez (2015), Balta ve Saraç (2016) ve Saraç'ın (2017) yapmış oldukları meta analiz çalışmalarında çalışma grubunun öğrenme düzeylerine göre elde edilen sonuç ile araştırmada Fen öğretimi sürecinde yapılandırmacı yaklaşım öğrenme halkası modelleri kullanımının öğrencilerin öğrenme ürünlerine etkisinin çalışma grubunun öğrenme düzeyine göre elde edilen sonuç benzerlik göstermemektedir.

Araştırma sonuçlarına genel olarak bakıldığında Fen öğretimi sürecinde yapılandırmacı yaklaşım öğrenme halkası modelleri kullanımının öğrencilerin öğrenme ürünlerine olan etkisinin geniş düzeyde olduğu tespit edilmiştir. Ayrıca Fen öğretimi sürecinde yapılandırmacı yaklaşım öğrenme halkası modelleri kullanımının etkililiği ile öğrenme ürünleri arasında, kullanılan öğrenme halkası modeli arasında, çalışmaların yapıldığı Fen alanları arasında ve çalışmaların yapıldığı öğrenim düzeyleri arasında istatistiksel olarak anlamlı düzeyde bir fark vardır. Bu fark öğrenme ürünlerinde kalıcılık, öğrenme halkası modellerinde 4E Modeli, Fen alanında Fen bilimler dersi ve öğrenme düzeyinde ise İlkokul öğrencileri lehinedir. Fen öğretimi sürecinde yapılandırmacı yaklaşım öğrenme halkası modelleri kullanımının etkililiği ile lisansüstü tez türleri arasında ise istatistiksel olarak anlamlı düzeyde bir fark yoktur.

$\mathrm{Bu}$ meta analiz çalışmasında Fen öğretimi sürecinde yapılandırmacı yaklaşım öğrenme halkası modelleri kullanımının öğrencilerin öğrenme ürünlerine etkisi akademik başarı, kalıcılık, derse olan tutum ve bilimsel süreç becerileri kategorilerinde incelenmiş ve bunun dışında kalan etkiler çalışma kapsamı dışında tutulmuştur. Bundan sonra bu konularda çalışma yapacak araştırmacılar eğitim-öğretim sürecinde öğrenme halkası modelleri kullanımının; cinsiyet ve kaygı gibi faktörler üzerine etkisi gibi farklı konularda meta-analiz çalışmaları gerçekleştirebilirler. Ayrıca bu meta-analizde yapılan çalışmada öğrenme halkası modelleri kullanımının öğrenilen bilgilerin kalıcı olmasında, 4E modelinde, Fen bilimleri dersinde ve ilkokul öğrencileri üzerinde daha etkili sonuçlar verdiği ortaya çıkmıştır. Bu sonuçların nedenlerine yönelik kapsamlı bir çalışma yapılabilir. Araştırma Fen öğretimi alanında yapılmıştır. Benzer çalışma tüm disiplin alanlarına uygulanabilir. Ayrıca eğitim-öğretim teknolojileri kapsamında daha çok teknolojik materyal içerikli olan çoklu ortam destekli uygulamaların öğrenme ürünlerine olan etkisinin dikkate alınabileceği meta analiz çalışmaları yapılabilir. 


\section{Extended Summary}

\section{Purpose and Significance}

The aim of the research is to decide the effect of constructivist approach learning cycle models usage in teaching science on students' academic success, the permanence of knowledge, their attitude towards lesson and scientific process skills through meta-analysis method. Accordingly, the question "What is the effect of constructivist approach learning cycle models usage in the process of teaching science on students' learning outcomes?” is tried to be answered. The sub-problems identified in this direction is as follows.

- Is there any effect on the academic achievement of that students learn using the learning cycle models in the process of national field teaching science?

- Is there any effect on the permanence of the information that students learn using the learning cycle models in the process of national field teaching science?

- Is there any effect on the attitude towards the lessons that students learn using the learning cycle models in the process of national field teaching science?

- Is there any effect on the scientific process skills that students learn using the learning cycle models in the process of national field teaching science?

- Do the effects of the studies using the learning cycle models on the learning environment of students in the national field of teaching science vary according to type of the learning cycle models?

- Do the effects of the studies using the learning cycle models on the learning environment of students in the national field of teaching science vary according to the graduate thesis?

- Do the effects of the studies using the learning cycle models in the process of national field education vary depending on the course areas of the students' impact on the learning products?

- Do the effects of the studies using the learning cycle models in the process of national field education vary depending on the learning levels of the students?

\section{Methodology}

Meta-analysis method is used in the study in order to detect the efficacy of $5 \mathrm{E}$ learning model usage universally in the process of education. In the meta-analysis method, quantitative data is obtained from experimental studies or quasiexperimental studies in any field and it is evaluated and compared congruously via statistical methods and also the effect of independent variable on dependent variable is defined.

The studies included in the research consist of doctorate and master dissertations which are evaluated statistically, published or not published universally through using the learning cycle models and have sufficient quantitative data in the years of 2007-2016. In the study, there are 2 or 3 different studies in 107 of postgraduate dissertations which are published about students' academic success, the permanence of the knowledge learned, their attitude towards the lesson and scientific process skills. When the effect of the learning cycle models usagein teaching science on students' learning outcomes is considered in general, totally 227 different studies including 107 postgraduate dissertations are included into meta-analysis method by calculating effect size.

The dependent variable of the study is effect sizes which are calculated for the effect of studies included in the meta-analysis on students' academic success, the permanence of knowledge, their attitude towards lesson and scientific process skills. However, independent variable of the study is lesson teaching method (the usage of the learning cycle models and traditional teaching methods). In the meta-analysis method, which statistical method will be used is decided through checking whether effect size displays homogenous distribution or not.

If effect size of Q homogeneity test is bigger than .05, distribution is accepted as homogenous and therefore, fixed effect model (FEM) is used. Nevertheless, if this size is under .05, random effect model (REM) is utilized. In meta-analysis method, various five groups in which efficacy of the learning cycle models usage can change in the education process are determined. These groups are learning outcomes categories, learning cycle models types, publication types, science field of the studies, education level of students who participated into study. Analysis of these subgroups are carried out and results are recorded. 


\section{Results}

In the research, 227 effect sizes from total 107 studies are calculated. 50 of them are obtained from PhD dissertation and 57 ones are from Master thesis. In experiment groups of the studies included in meta-analysis, there are totally 9006 students and in control groups, there are 8892 students. Homogenous level of studies included in the research is found as $\mathrm{Q}=2429.72$ and $\mathrm{p}=.00$ according to fixed effect model. Since $\mathrm{p}$ value is smaller than .05 according to significance level, it is claimed that there is statistically significant difference between independent variables. Therefore, it is seen that the effect size of the study is heterogonous. That's why analysis is carried out randomly according to random effect model (REM).

As a result of the analysis done according to random effects model, average effect size is found as .054 and it is .967 with standard error. Between reliability level 95\%, the low level of effect size is .862 and high level is 1.072 . Positive result of the average effect size puts forward that lessons taught through interactive boards are more effective than traditional teaching methods. This effect is large according to Thalheimer and Cook's (2002) classification. One of the subjects that need to be taken into consideration is publication bias. In order to bring down the effect size .967 which is obtained from analysis fulfilled with Orwin method to 0 , it is decided that 11051 studies whose effect size is 0 are required. This number is too high and it shows that publication bias is low.

\section{Discussion and Conclusion}

In the analysis of subgroups, there is significant difference in learning outcomes ( $\left.\mathrm{Q}_{\mathrm{B}}=46.091, \mathrm{p}<.05\right)$, the type of learning cycle models $\left(\mathrm{Q}_{\mathrm{B}}=8.868, \mathrm{p}<.05\right)$, science field of studies $\left(\mathrm{Q}_{\mathrm{B}}=13.668, \mathrm{p}<.05\right)$ and education level of students $\left(\mathrm{Q}_{\mathrm{B}}=9.568, \mathrm{p}<.05\right)$ and there is no significant difference in publication types $\left(\mathrm{Q}_{\mathrm{B}}=3.662, \mathrm{p}>.05\right)$. When the results of the research are examined in general, it is determined that the effect of the learning cycle models usage in teaching science on learning outcomes is at the large level. Moreover, there is statistically significant difference between the efficacy of the learning cycle models in teaching science and academic success, permanence, attitude towards lesson, scientific process skills, type odhe learning models, science field and students' education levels. There is not statistically significant difference between the efficacy of the learning cycle models in publication type. 


\section{Kaynakça / References}

Açıkel, C. (2009). Meta analiz ve kanıta dayalı analizin tıptaki yeri. Klinik Psikofarmoloji Bülteni, 19(2), 164-172.

Akpınar, E., \& Ergin, Ö. (2005). Yapılandırmacı kuramda fen öğretmeninin rolü, İlköğretim Online, 4(2), 55-64.

Aktamış, H., \& Özden, B. (2016). Effects of the Inquiry-Based Learning Method on students’ achievement, science process skills and attitudes towards science: A meta-analysis science. Journal of Turkish Science Education, 13(4), 248-261.

Appleton, S. (1997). Problems of measuring changes in poverty over time: the case of Uganda 1989-1992. Institute of Development Studies Bulletin, 27(1), 43-55.

Ayaz, M. F. (2015). 5E öğrenme modelinin öğrencilerin derslere yönelik tutumlarına etkisi: Bir meta-analiz çalışması. Electronic Journal of Education Sciences, 4(7), 29-50.

Ayaz, M. F. (2015). Probleme dayalı öğrenme yaklaşımının öğrencilerin fen derslerindeki akademik başarılarına etkisi: Bir metaanaliz çalışması. Turkish Studies-International Periodical for the Languages, Literature and History of Turkish or Turkic, 10(3), 139-160.

Ayaz, M. F., \& Söylemez, M. (2015). Proje tabanlı öğrenme yaklaşımının Türkiye'deki öğrencilerin fen derslerindeki akademik başarılarına etkisi: Bir meta-analiz çalışması. Eğitim ve Bilim, 40(178), 255-283.

Ayaz, M. F., \& Şekerci, H. (2015). Yapılandırmacı öğrenme yaklaşımının akademik başarıya ve tutuma etkisi: Bir meta-analiz çalışması. Hasan Âli Yücel Eğitim Fakültesi Dergisi, 12(2), 27-44.

Balım, A. G., Türkoğuz, S., Aydın, G., \& Evrekli, E. (2012). Fen ve teknoloji dersinin “madde ve ısı" konularında yapılandırmacı yaklaşımın 7E modeline dayalı etkinlik planları. Bartın Üniversitesi Eğitim Fakültesi Dergisi, 1(1), 128-139.

Balta, N., \& Sarac, H. (2016). The effect of 7E Learning Cycle on learning in science teaching: A meta-analysis study. European Journal of Educational Research, 5(2), 61-72.

Baker, D. R., \& Piburn, M. D. (1997). Constructing science in middle and secondary school classrooms. Boston, MA: Allyn and Bacon.

Bilgin, İ., Ay, Y., \& Coşkun, H. (2013). 5e öğrenme modelinin ilköğretim 4. Sınıf öğrencilerinin madde konusundaki başarılarına etkisinin ve model hakkında öğrenci görüşlerinin incelenmesi. Kastamonu Eğitim Dergisi, 21(4), 1449-1470.

Bodner, G. M. (1990). Why good teaching fails and hard-working students do not always succeed? Spectrum, 28(1), 27-32.

Boddy, N.,Watson, K., \& Aubusson, P. (2003). A trial of the Five Es: A referant model for constructivist teaching and learning. Research in Science Education, 33, 27-42.

Borenstein, M., Hedges, L.V., Higgins, J. P. T., \& Rothstein, H. R. (2013). Introduction to meta analysis. London: John Wiley \& Sons.

Bozdemir, H., Çevik, E. E., Altunoğlu, B. D., \& Kurnaz, M. A. (2017). Astronomi konularının öğretiminde kullanılan farklı yöntemlerin akademik başarıya etkisi: Bir meta analiz çalışması. Alan Eğitimi Araştırmaları Dergisi (ALEG), 3(1), 12-24.

Bulut, H. (2012). Eşeyli üreme ve mayoz bölünme konusunda $7 E$ modelinin başarlya etkisinin araşttrılması (Yayınlanmamış yüksek lisans tezi). Atatürk Üniversitesi, Erzurum.

Bybee, R. W. (1997). Achieving scientific literacy: From purposes to practices. Westport, CT: Heinemann.

Bybee, R. W. (2003). Achieving scientific literacy: From purposes to practices. Portsmouth: Heinemann.

Cohen, J., Manion, L., \& Morrison, K. (2007). Research methods in education (6th ed.). New York, NY: Routledge.

Cooper, H., Hedges, L. V., \& Valentine, J. C. (2009). The handbook of research synthesis and meta analysis (2nd ed.). New York, NY: Russell Sage Publication.

Çoruhlu, T. Ş., \& Çepni, S. (2016). Zenginleştirilmiş 5e modelinin öğrenci kavramsal değişimi üzerine etkisi: Astronomi örneği. Kastamonu Ĕ̆itim Dergisi, 24(4), 1785-1802. 
Çepni, S., Akdeniz, A. R., \& Keser, Ö. F. (2000). Fen bilimleri öğretiminde bütünleştirici öğrenme kuramına uygun örnek rehber materyallerin geliştirilmesi. Fırat Üniversitesi 19. Fizik Kongresi, Elazı̆̆.

Çepni, S., Şan, H. M., Gökdere, M., \& Küçük, M. (2001). Fen bilgisi öğretiminde zihinde yapılanma kuramına uygun 7E modeline göre örnek etkinlik geliştirme. Yeni Binyılın Başlangıcında Türkiye'de Fen Bilimleri Eğitimi Sempozyumu (ss. 83-92).

Demir, C., \& Maskan, A. K. (2012). Web destekli öğrenme halkası yaklaşımının lise 11. sınıf öğrencilerinin fizik dersi öz-yeterlik inançlarına etkisi. Dicle University Journal of Ziya Gökalp Education Faculty, 18, 17-30.

Demir, C., \& Maskan, A. K. (2014). Web destekli öğrenme halkası yaklaşımı uygulamalarına ilişkin öğrenci görüşleri. Journal of Computer and Education Research, 2(3), 136-150.

Demirel, Ö., \& Yurdakul, B. (2007). Eğitimde yeni yönelimler. Ankara: Pegem A Yayınc1lık.

Dinçer, S., \& Güçlü, M. (2013). Fen bilgisi eğitiminde bilgisayar destekli simülasyon kullanımının etkililiği ve yeni yönelimler: Bir meta-analiz çalışması. International Journal of Human Sciences, 10, 35-48.

Eisenkraft, A. (2003). Expanding the 5e model. The Science Teacher, 70(6), 56-59.

Ellis, P. D. (2010). The essential guide to effect sizes: Statistical power, meta-analysis, and the interpretation of research results. Cambridge: Cambridge University Press.

Ergin, İ. (2012). Fen eğitiminde 5E Modeli ile ilgili yazılı kaynaklar dizini. Eğitim ve Öğretim Araştırmaları Dergisi, $1(1)$, 53-67.

Hand, B., \& Treagust, D. F. (1991). Student achievement and science curriculum development using a constructivist framework. School Science and Mathematics, 91(4), 172-176.

Harurluoğlu, Y., \& Kaya, E. (2011). Öğrenme halkası modelinin fen bilgisi öğretmen adaylarının tohum-meyve-çiçek konularındaki başarılarına ve hatırlama düzeylerine etkisi. Ĭgdır Üniversitesi Fen Bilimleri Enstitüsü Dergisi, 1(4), 43-50.

Hedges, L.V., \& Olkin, I. (1985). Statistical methods for meta-analysis. New York, NY: Academic Press.

Kanlı, U. (2009). Yapılandırmacı kuramın 1şı̆̆ında öğrenme halkasının kökleri ve evrimi: Örnek bir etkinlik. Ĕgitim ve Bilim Dergisi, 34(151), 44-64.

Keleş, Y. (2010). Fen eğitiminde öğrenme döngüsü modelleri. Mersin Üniversitesi Eğitim Fakültesi Dergisi, 6(1), $41-51$.

Küçük, Z., \& Çalık, M. (2015). Effect of Enriched 5Es Model on grade 7 students' conceptual change levels: A case of 'Electric Current' subject. Adlyaman University Journal of Educational Sciences, 5(1), 1-28.

Lipsey, M., \& Wilson, D. (2001). Practical meta-analysis. Beverly Hills, CA: Sage Publications.

Meşeci, B., \& Karamustafaoğlu, S. (2015). Maddenin tanecikli yapısı ünitesine yönelik 4E Modeli destekli etkinliklerin akademik başarıya etkisi. Karaelmas Ĕ̆itim Bilimleri Dergisi, 3(1), 1-12.

Miles, M. B., \& Huberman, A. M. (2002). The qualitative researcher's companion. Thousand Oaks, CA: Sage Publications.

Özaydın, T.E. (2010). İlköğretim yedinci sınıf fen ve teknoloji dersinde 5 E öğrenme halkası ve bilimsel süreç becerileri doğrultusunda uygulanan etkinliklerin, ögrencilerin akademik başarıları, bilimsel süreç becerileri ve derse yönelik tutumlarına etkisi (Yayınlanmamış yüksek lisans tezi). Dokuz Eylül Üniversitesi, İzmir.

Özmen, H. (2004). Fen öğretiminde öğrenme teorileri ve teknoloji destekli yapılandırmacı öğrenme. The Turkish Online Journal of Educational Technology, 3(1), 100-111.

Öztürk, H. İ., \& Karakuş, M. (2016). Türkiye'de uygulanan işbirliğine dayalı öğrenme yönteminin fen bilimleri öğretiminde akademik başarı ve derse karşı tutumlar üzerindeki etkisini incelemeye yönelik bir meta-analiz çalışması. International Journal of Active Learning, 1(1), 1-28.

Renner, J. W., Abraham, R. M., \& Birnie, H. H. (1998). The necessity of eachphase of the learning cycle in teaching high school. Journal of Research in Science Teaching, 28, 437-454. 
Saraç, H. (2017). Türk eğitim sisteminde akıllı tahta kullanımının öğrencilerin öğrenme ürünlerine etkisi: Meta analiz çalışması, Turkish Studies - International Periodical for the Languages, Literature and History of Turkish or Turkic, 12(4), 445-470.

Saraç, H. (2015). Çoklu ortam destekli 7E Modeline göre tasarlanan uygulamaların 5. sınıf fen bilimleri dersi “Maddenin Değişimi” ünitesinde öğrencilerin öğrenme ürünlerine etkisi (Yayınlanmamış doktora tezi). Dumlupınar Üniversitesi, Kütahya.

Saraç, H., \& Kunt, H. (2016). Yapılandırmacı Yaklaşım 7e Öğrenme Halkası Modeli ile ilgili yapılan araştırmalar: İçerik analizi çalışması. Electronic Turkish Studies, 11(9), 701-724.

Şadoğlu, G. P., \& Akdeniz, A. R. (2015). 7e Öğrenme Modeline yönelik tasarlanan materyallerin lise öğrencilerinin modern fizik başarılarına etkisi. Journal of Computer and Education Research, 3(5), 96-129.

Şahin, M. C. (2005). Internet tabanlı uzaktan ĕgitimin etkililiği: Bir meta-analiz çalışması (Yayınlanmamış yüksek lisans tezi). Çukurova Üniversitesi, Adana.

Şaşmaz Ören, F., \& Tezcan, R. (2009). The effectiveness of the Learning Cycle Aproach on learners' attitude toward science in seventh grade science classes of elemantary school. Elemantary Educational Online, 8(1), 103-118.

Temel, S., Özgür, S. D., \& Yılmaz, A. (2012). The effect of Learning Cycle Model on preservice chemistry teachers' understanding of oxidation reduction topic and thinking skills. Necatibey Faculty of Education Electronic Journal of Science and Mathematics Education, 6(1), 287-305.

Thalheimer, W., \& Cook, S. (2002). How to calculate effect sizes from published research articles: A simplified methodology. A Work-Learning Research Publication (http://www.bwgriffin.com/gsu/courses/edur9131/content/Effect_Sizes_pdf5.pdf)

Tonbuloğlu, B. (2014). Mustafa Satı Bey’in görüşleri doğrultusunda yapılandırmacılık anlayışına farklı bir bakış açısı. Turkish Studies - International Periodical for the Languages, Literature and History of Turkish or Turkic, 9(8), 70-78.

Turgut, U., Colak, A., \& Salar, R. (2016). The effect of 7E Model on conceptual success of students in the unit of electromagnetism. European Journal of Physics Education, 7(3), 1-37.

Turgut, Ü., Gürbüz, F., \& Salar, R. (2013). The effect of 7e model on academic achievements andretention in the unit "electricity in our life" 6th grade science and technology course. Educationand Development Conference, March 04-05, Valencia, Spain.

Türkmen, H. (2006). Öğrenme döngüsü yaklaşımıyla ilköğretimde fen nasıl öğretilmelidir? Elementary Education Online, 5(2), 115.

Ural, G., \& Bümen, N. (2016). Türkiye’de fen ve teknoloji öğretiminde yapılandırmacılığın öğretimsel uygulamaları üzerine bir meta-analiz. Eğitim ve Bilim, 41(185), 51-82.

Üstün, U., \& Eryılmaz, A. (2014). Etkili araştırma sentezleri yapabilmek için bir araştırma yöntemi: Meta-analiz. Eğitim ve Bilim, 39(174), 1-32.

Wilder, M., \& Shuttleworth, P. (2004). Cell inquiry: A 5E learning cycle lesson. Science Activities, 41(1), 25-31.

Wolf, F. M. (1988). Meta-analysis quantitative methods for research synthesis (3rd ed.). Thousand Oaks, CA: Sage Publications.

Yenice, E. (2014). Yapılandırmacı yaklaşımın 7e Öğrenme Modelinin 8. sınıf fen ve teknoloji dersi "mitoz ve mayoz bölünme" konusunda öğrencilerin akademik başarılarına etkisinin incelenmesi (Yayınlanmamış yüksek lisans tezi). Kafkas Üniversitesi, Kars.

Yesilyurt, M. (2011). Meta-analysis of the computer assisted studies in physics: A sample of Turkey. Energy Educ Sci Technol Part B, 3, 173-182.

Yıldırım, A., \& Şimşek, H. (2011). Sosyal bilimlerde nitel araştırma yöntemleri. Ankara: Seçkin Yayınevi. 
Ek 1. Öğrenme Halkası Modelleri Meta Analiz Çalışmasına Dahil Edilen Lisansüstü Tezler

Abdüsselam, Z. (2013). Animasyon destekli çizgi filmlerin fen öğretimine etkisi: 6. Sınıf Kuvveti Keşfedelim konusu örneği (Yayımlanmamış doktora tezi). Karadeniz Teknik Üniversitesi, Trabzon.

Açışlı, S. (2010). Fizik laboratuvar uygulamalarında 5E Öğrenme Modeline uygun olarak geliştirilen materyallerin öğrenci kazanımlarına etkisinin incelenmesi (Yayınlanmamış doktora tezi). Atatürk Üniversitesi, Erzurum.

Ağgül-Yalçın, F. (2010). Ortaöğretim ve yükseköğretim düzeyinde asit-baz konusunun öğretimi için yapılandırmacı yaklaşıma uygun aktif ögrenme etkinliklerinin hazırlanması, uygulanması ve değerlendirilmesi (Yayınlanmamış doktora tezi). Atatürk Üniversitesi, Erzurum.

Akgündüz, D. (2013). Fen ĕgitiminde harmanlanmış öğrenme ve sosyal medya destekli öğrenmenin öğrencilerin başarı, motivasyon, tutum ve kendi kendine ögrenme becerilerine etkisi (Yayınlanmamış doktora tezi). Marmara Üniversitesi, İstanbul.

Akpınar, İ. A. (2010). Kimyada çözeltiler konusunun öğretimi için yapılandırmacı yaklaşıma uygun aktif öğrenme etkinliklerinin geliştirilerek uygulanması ve değerlendirilmesi (Yayınlanmamış doktora tezi). Atatürk Üniversitesi, Erzurum.

Akpınar, M. (2012). Bă̆lam temelli yaklaşımla yapılan fizik ĕgitiminde kavramsal değişim metinlerinin öğrenci erişisine etkisi (Yayınlanmamış doktora tezi). Gazi Üniversitesi, Ankara.

Aktaş, M. (2013). 5E ögrenme modeli ve işbirlikli öğrenme yönteminin biyoloji dersi tutumuna etkisi (Yayınlanmamış doktora tezi). Gazi Üniversitesi, Ankara.

Altan, S. T. (2015). Araştırmaya dayalı öğrenme yöntemiyle ilkokul öğrencilerinde başarı ve bilimsel süreç becerilerinin geliştirilmesi (Yayınlanmamış yüksek lisans tezi). Marmara Üniversitesi, İstanbul.

Altınay, Ö. (2009). 5E modeline dayalı öğretim yönteminin ögrencilerin genetikle ilgili DNA, gen ve kromozom kavramlarını ögrenmelerine etkisi (Yayınlanmamış yüksek lisans tezi). Balıkesir Üniversitesi, Balıkesir.

Andaç, K. (2007). Gözden geçirme stratejisi ile desteklenmiş yapılandırmacı öğrenme yaklaşımının 5E modelinin öğrencilerin basınç konusundaki erişilerine, bilgilerinin kalıcılığına ve tutumlarına etkisi (Yayınlanmamış yüksek lisans tezi). Dicle Üniversitesi, Diyarbakir.

Arslan, H. Ö. (2014). The effect of 5e Learning Cycle instruction on 10th grade students' understanding of cell division and reproduction concepts (Unpublished doctoral dissertation). Middle East Technical University, Ankara.

Artun, H. (2009). Difüzyon ve osmoz kavramlarına yönelik 5E Modeline uygun öğretim materyalinin geliştirilmesi ve değerlendirilmesi (Yayınlanmamış yüksek lisans tezi). Karadeniz Teknik Üniversitesi, Trabzon.

Atılboz, N. G. (2007). Öğrenme halkası modelinin biyoloji öğretmen adaylarının difüzyon ve osmoz konularını öğrenmeleri, biyoloji ögretimine yönelik özyeterlik inançlarl ve tutumları üzerine etkileri (Yayınlanmamış doktora tezi). Gazi Üniversitesi, Ankara.

Avcığlu, O. (2008). Lise 2 fizik dersinde Newton Yasaları konusunda $7 E$ Modelinin başarıya etkisinin araştırılması (Yayınlanmamış yüksek lisans tezi). Gazi Üniversitesi, Ankara.

Aydemir, N. (2012). 5E Öğrenme Modelinin Lise Öğrencilerinin Çözünürlük Dengesi Konusunu Anlamasına Etkisi (Yayınlanmamış doktora tezi). Orta Doğu Teknik Üniversitesi, Ankara.

Aydin, N. (2010). The effect of constructivist approach in chemistry Education on students' higher order cognitive skills (Unpublished doctoral dissertation). Hacettepe University, Ankara.

Aydoğmuş, E. (2008). Lise 2 fizik dersi iş-enerji konusunun öğretiminde 5 E modelinin öğrenci başarısına etkisi (Yayınlanmamış yüksek lisans tezi). Selçuk Üniversitesi, Konya.

Bal, E. (2012). 5 E modeli Merkezli Laboratuvar Yaklaşımının Fizik Laboratuvarı Dersinde Fen Bilgisi Öğretmen Adaylarının Tutum ve Başarllarına Etkisi (Yayınlanmamış yüksek lisans tezi). Kastamonu Üniversitesi, Kastamonu.

Bektas, O. (2011). The effect of 5 E learning cycle model on tenth grade students' understanding in the particulate nature of matter, epistemological beliefs and views of nature of science (Unpublished doctoral dissertation). Middle East Technical University, Ankara.

Bıyıklı, C. (2013). 5E öğrenme modeline göre düzenlenmiş eğitim durumlarının bilimsel süreç becerileri, öğrenme düzeyi ve tutuma etkisi (Yayınlanmamış doktora tezi). Hacettepe Üniversitesi, Ankara.

Bulbul, Y. (2010). Effects of 7e learning cycle model accompanied with computer animations on understanding of diffusion and osmosis concepts (Unpublished doctoral dissertation). Middle East Technical University, Ankara.

Bulut, H. (2012). Sexual reproduction and meiosis 7E model investigating the impact of success (Unpublished master thesis). Atatürk University, Erzurum.

Burkaz, S. (2012). Fen ve Teknoloji Öğretiminde Üç Boyutlu Modellerin Yapılandırmacı Öğrenme Ortamında Kullanımı (Yayınlanmamış yüksek lisans tezi). Recep Tayyip Erdoğan Üniversitesi, Rize.

Can, H. (2016). Yaşam temelli usl ve sicaklık konusu ögretiminin sekizinci sınıf öğrencilerinin kavramsal anlamalarına etkisi (Yayınlanmamış yüksek lisans tezi). Balıkesir Üniversitesi, Balıkesir.

Ceylan, E. (2008). Effects of 5 E learning cycle model on understanding of state of matter and solubility concepts (Unpublished doctoral dissertation). Middle East Technical University, Ankara.

Ceylan, Ö. (2015). Fen Öğretiminde Kavram Karikatürü Kullanımının 7. Sınıf Öğrencilerinin Akademik Başarılarına ve Bilişsel Yapılarına Etkisinin İncelenmesi (Yayınlanmamış yüksek lisans tezi). Sakarya Üniversitesi, Sakarya.

Çavuş, E. (2015). Fen ve teknoloji dersinde fen günlüğ̈̈ kullanımının ilköğretim ögrencilerinin bilişüstü farkındalık ve akademik başarısına etkisi (Yayınlanmamış yüksek lisans tezi). Adıyaman Üniversitesi, Adıyaman.

Çekilmez, S. (2014). The effect of 7E model on success and attitude of the students during the instruction of electric chapter at physics course of second level of high school (Unpublished master thesis). Necmettin Erbakan Üniversitesi, Konya. 
Çolak, Ö. (2014). Sorgulayıcı-Araştırmaya Dayalı Fen Öğretimi Yönteminin Fen Okuryazarlı̆̆l ve Bazı Alt-Boyutları Üzerine Etkisi (Yayınlanmamış yüksek lisans tezi). Trakya Üniversitesi, Edirne.

Coşkun, H. (2011). 5E öğrenme modelinin ilköğretim 4. sınıf öğrencilerinin maddeyi tanıyalım ünitesindeki başarl, tutum ve zihinsel yapılarına etkisi (Yayınlanmamış yüksek lisans tezi). Mustafa Kemal Üniversitesi, Hatay.

Çoruhlu, T. Ş. (2013). Güneş Sistemi ve Ötesi Uzay Bilmecesi” ünitesinde zenginleştirilmiş 5E öğretim modeline göre geliştirilen rehber materyallerin etkililiğinin belirlenmesi (Yayınlanmamış doktora tezi). Karadeniz Teknik Üniversitesi, Trabzon.

Damar, S. Y. (2013). The Effect Of The Instruction Based On The Epistemologically And Metacognitively Improved 7E Learning Cycle On Tenth Grade Students'achievement And Epistemological Understandings In Physics (Unpublished doctoral dissertation). Middle East Technical University, Ankara.

Demir, C. (2010). Web Destekli Öğrenme Halkası Yaklaşımı'nın Lise 3. Sınıf Öğrencilerinin Fizik (Yeryüzünde Hareket Konusu) Başarıları ve Öz-yeterlik Algılarına Etkisi (Yayınlanmamış doktora tezi). Dicle Üniversitesi Diyarbakır.

Demirezen, S. (2010). The effect of $7 E$ model to students achievement, development of scientific process skills, conceptual achievement and retention levels in electrical circuits subject (Unpublished doctoral dissertation). Gazi Üniversitesi, Ankara.

Deren, Ş. (2008). İlköğretim 8. sinıf genetik ünitesinin 5e modeline göre tasarlanan multimedya destekli ögretimin öğrencilerin erişi ve tutumlarına etkisi (Yayınlanmamış yüksek lisans tezi). Muğla Üniversitesi, Muğla.

Dindar, A.Ç. (2012). The effect of 5E learning cycle model on eleventh grade students' conceptual understanding of acids and bases concepts and motivation to learn chemistry (Unpublished doctoral dissertation). Middle East Technical University, Ankara.

Ekici, F. (2007). Yapılandırmacı Yaklaşıma Uygun 5E Öğrenme Döngüsüne Göre Hazırlanan Ders Materyalinin Lise 3. sınıf Ögrencilerinin Yükseltgenme-İndirgenme Tepkimeleri ve Elektrokimya Konulart Anlamalarına Etkisi (Yayınlanmamış yüksek lisans tezi). Gazi Üniversitesi, Ankara.

Ercan, O. (2014). Effect of $5 E$ learning cycle and V diagram use in general chemistry laboratories on science teacher candidates 'attitudes, anxiety and achievement (Unpublished doctoral dissertation). Gazi Üniversitesi, Ankara.

Ercan, S. (2009). Yapılandırmacı öğrenme yaklaşımı 5E öğretim modelinin madde döngüleri konusunun öğretilmesine etkisi (Yayınlanmamış yüksek lisans tezi). Gazi Üniversitesi, Ankara.

Erdoğdu, S. (2011). Elektrik konularının 5E Modeli'ne göre öğretiminin öğrencilerin akademik başarılarına ve tutumlarına etkisi. Doctoral dissertation, Selçuk Üniversitesi, Konya.

Er Nas, S. (2008). Isının yayılma yolları konusunda 5 E modelinin derinleşme aşamasına yönelik olarak geliştirilen materyallerin etkililiğinin değerlendirilmesi (Yayınlanmamış yüksek lisans tezi). Karadeniz Teknik Üniversitesi, Trabzon.

Ersoy, İ. (2011). Elektrik-manyetizma konusunun işlenişinde, $5 E$ modelinin derinleşme aşamasına yönelik geliştirilen materyallerin ögrenci başarısına etkisinin değerlendirilmesi (Yayınlanmamış doktora tezi). Selçuk Üniversitesi Eğitim Bilimleri Enstitüsü, Konya.

Ertuğrul, N. (2015). Fen Bilimleri Öğretiminde Ortak Bilgi Yapılandırma Modelinin Öğrenme Ürünlerine Etkisi (Yayınlanmamış yüksek lisans tezi). Kırıkkale Üniversitesi, Kırıkkale.

Ezberci, E. (2014). Üst kavramsal Faaliyetleri Aktif Hale Getirici Etkinliklerle Desteklenmiş 5 E Öğrenme Döngüsü Modelinin 7. Sını Öğrencilerinin Ay'ın Evreleri Konusundaki Kavramsal Anlamalarına Etkisi (Yayınlanmamış yüksek lisans tezi). Gazi Üniversitesi, Eğitim Bilimleri Enstitüsü, Ankara.

Gezer, S. U. (2014). Yansıtıcı Sorgulamaya Dayalı Genel Biyoloji Laboratuvarı Etkinliklerinin Fen Bilgisi Öğretmen Adaylarının Laboratuvar Kullanımı Özyeterlik Algıları, Eleştirel Düşünme Eğilimleri ve Bilimsel Süreç Becerileri Üzerine Etkisi (Yayınlanmamış doktora tezi). Marmara Üniversitesi, İstanbul.

Gök, G. (2014). The Effect Of 7E Learning Cycle Instruction On 6 Th Grade Students 'Conceptual Understanding Of Human Body Systems, Self-Regulation, Scientific Epistemological Beliefs, And Science Process Skills (Unpublished doctoral dissertation). Middle East Technical University, Ankara.

Gül, Ş. (2011). 5E modeline dayalı olarak hazırlanan ders yazılımının öğrencilerin başarılarına, tutumlarına ve kavram yanılgılarının giderilmesine etkisi (Yayınlanmamış doktora tezi). Atatürk Üniversitesi, Erzurum.

Gündüz Bahadır, E. B. (2012). Animasyon tekniği ve 5E öğrenme modelinin 8. Sinıf “yaşamımızdaki elektrik” ünitesinin işlenmesinde akademik başarı, tutum ve eleştirel düşünebilme yeteneklerine etkisinin araştırllması (Yayınlanmamış yüksek lisans tezi). Atatürk Üniversitesi, Erzurum.

Gürbüz, F. (2012). The effect of 7e learning model on academic achievements and retention of students in the unit of "electricity in our life" 6th grade science and technology course (Unpublished doctoral dissertation. Atatürk Üniversitesi, Erzurum.

Haras, Ö. (2009). Üreme" ünitesinin 5E modeline göre ögretiminin ögrrencilerin kavramsal anlama ve tutumlarl üzerine etkisi (Yayınlanmamış doktora tezi). Dokuz Eylül Üniversitesi, İzmir.

Harurluoğlu, Y. (2011). Öğrenme halkası modelinin fen bilgisi ögretmen adaylarının tohum-meyve-çiçek konularındaki başarılarına ve hatırlama düzeylerine etkisi (Yayınlanmamış doktora tezi). Atatürk Üniversitesi, Erzurum.

Hırça, N. (2008). 5E modeline göre "iş, güç ve enerji” ünitesiyle Illgili geliştirilen materyallerin kavramsal değişime etkisinin incelenmesi (Yayınlanmamış doktora tezi). Atatürk Üniversitesi, Erzurum.

İstanbuloğlu, B. (2014). Bilgisayar Destekli 5E Öğrenme Halkası Modelinin Öğrenci Başarısı Üzerine Etkisi (Yayınlanmamış yüksek lisans tezi). Kırıkkale Üniversitesi, Kırıkkale.

Kanlı, U. (2007). 7E modeli merkezli laboratuvar yaklaşımı ile doğrulama laboratuvar yaklaşımlarının öğrencilerin bilimsel süreç becerilerinin gelişimine ve kavramsal başarılarına etkisi. (Yayınlanmamış yüksek lisans tezi). Gazi Üniversitesi, Ankara. 
Kara, F. (2016). 5. Sınıf "Maddenin Değişimi” Ünitesinde Kullanılan Bă̆lam Temelli Öğrenmenin Öğrencilerin Bilgilerini Günlük Yaşamla Ilişsilendirme Düzeyleri, Akademik Başarıları ve Fene Yönelik Tutumlarına Etkisi (Yayınlanmamış doktora tezi). 19 Mayıs Üniversitesi, Samsun.

Karslı, F. (2011). Fen bilgisi öğretmen adaylarının bilimsel süreç becerilerini geliştirmesinde ve kavramsal değişim sağlamasında zenginleştirilmiş laboratuar rehber materyallerinin etkisi (Yayınlanmamış doktora tezi). Karadeniz Teknik Üniversitesi, Trabzon.

Kaynar, D. (2007). The effect of 5E learning cycle approach on sixth grade students' understanding of cell concept, attitude toward science and scientific epistemological beliefs (Unpublished master thesis). Middle East Technical University, Ankara.

Kenan, O. (2014). “Maddenin Tanecikli Yapısı” Ünitesine Yönelik Zenginleştirilmiş Bilgisayar Destekli Öğretim Materyalinin Geliştirilmesi ve Etkililiğinin Araştırılması (Yayınlanmamış doktora tezi). Karadeniz Teknik Üniversitesi, Trabzon.

Keskin, V. (2008). Yapılandırmacı 5E öğrenme modelinin lise ögrencilerinin basit sarkaç kavramları ögrenmelerine ve tutumlarına etkisi (Yayınlanmamış yüksek lisans tezi). Marmara Üniversitesi, İstanbul.

Koç, R.S. (2013). 5E Modeli İle Desteklenen Bağlam Temelli Yaklaşımın Yedinci Sınıf Öğrencilerinin Işık Ünitesindeki Başarılarına, Bilgilerinin Kalıcılı̆̆ına ve Fen Dersine Karşı Olan Tutumlarına Etkisi (Yayınlanmamış doktora tezi). Gazi Üniversitesi, Ankara.

Koçak, C. (2011). Kimya Konularının Günlük Yaşam Konsepti Çerçevesinde Değerlendirilmesi (Yayınlanmamış doktora tezi). Hacettepe Üniversitesi, Ankara.

Kolomuç, A. (2009). 11. Sinıf “Kimyasal Reaksiyonların Hızları” Ünitesinin 5E Modeline Göre Animasyon Destekli Öğretimi (Yayınlanmamış doktora tezi). Atatürk Üniversitesi, Erzurum.

Kunduz, N. (2013). Development and application of 7E learning model based computer-assisted teaching materials on precipitation titrations (Unpublished master thesis). Hacettepe Üniversitesi, Ankara.

Küçük, Z. (2011). Zenginleştirilmiş 5E modelinin 7. sınıf öğrencilerinin kavramsal değişime etkisi: Elektrik akımı örneği (Yayınlanmamış yüksek lisans tezi). Karadeniz Teknik Üniversitesi, Trabzon.

Kürkçü, E. (2016). Lise 1. Sinıf Biyoloji Dersi “Canlının Temel Birimi Hücre” Konusunun Öğretiminde 5E Modelinin Öğrenci Başarısı ve Tutumuna Etkisi (Yayınlanmamış yüksek lisans tezi). Gazi Üniversitesi, Ankara.

Masattaş, M. (2012). 8. Sinıf Elektrik Ünitesi’ne Yönelik Hazırlanan Materyaller'in Etkililiğinin Öğrenci Görüşleri’ne Göre Değerlendirilmesi (Yayınlanmamış yüksek lisans tezi). Karadeniz Teknik Üniversitesi, Trabzon.

Meşeci, B. (2013). Maddenin Tanecikli Yapısı Ünitesine Yönelik 4E Modeli Destekli Etkinliklerin Akademik Başarıya Etkisi (Yayınlanmamış yüksek lisans tezi). Amasya Üniversitesi, Amasya.

Meydan, A. M. (2015). The effect of the 7E learning method implemented in the subject of the structure of atom on the academic achievement and attitude of students (Unpublished master thesis). İbrahim Çeçen Üniversitesi, Ağrı.

Okur, M. (2009). Kavramsal değişimi să̆layan farklı metotların karşılaştırılması: sesin yayılması konusu örneği (Yayınlanmamış yüksek lisans tezi). Karadeniz Teknik Üniversitesi, Trabzon.

Önder, E. (2011). Fen ve teknoloji dersi" canlılarda üreme, büyüme ve gelişme" ünitesinde kullanılan yapılandırmacı 5E ögrenme modeli'nin 6. sınıf ögrencilerinin başarılarına etkisi (Yayınlanmamış doktora tezi). Selçuk Üniversitesi, Konya.

Öz, R. (2009). Araştırma ve Sorgulamaya Dayalı Etkinliklerle Desteklenmiş Bilim Merkezi Uygulamalarının 7. Sınıf Öğrencilerinin Akademik Başarllarına, Bilim Okuryazarlıklarına ve Sorgulayıcı Düşünme Becerilerine Etkisi (Yayınlanmamış yüksek lisans tezi). Marmara Üniversitesi, İstanbul.

Özalp, I. (2007). Karikatür tekniğinin fen ve çevre eğitiminde kullanılabilirliği üzerine bir araştırma. (Yayınlanmamış yüksek lisans tezi). Celal Bayar Üniversitesi, Manisa.

Özaydın, T.E. (2010). İlkögrretim yedinci sınıf fen ve teknoloji dersinde 5E ögrenme halkası ve bilimsel süreç becerileri doğrultusunda uygulanan etkinliklerin, ögrencilerin akademik başarları, bilimsel süreç becerileri ve derse yönelik tutumlarına etkisi (Yayınlanmamıș doktora tezi). Ege Üniversitesi, İzmir.

Özbayrak, Ö. (2013). Kimya Öğretiminde Kavram Yanılgıları: Bileşikler (Yayınlanmamış doktora tezi). Dokuz Eylül Üniversitesi, İzmir.

Özçelik, E. (2015). Fizik Öğretiminde Akıllı Tahta Kullanımının Öğrenci Başarısına Etkisinin Araştırılması (Yayınlanmamış yüksek lisans tezi). Atatürk Üniversitesi, Erzurum.

Özsevgeç, T. (2007). Illköğretim 5. sınıf kuvvet ve hareket ünitesine yönelik 5E modeline göre geliştirilen rehber materyallerin etkililiklerinin belirlenmesi (Yayınlanmamış doktora tezi). Karadeniz Teknik Üniversitesi, Trabzon.

Öztaş, E. (2016). Biyoloji Öğretiminde Bilgisayar Destekli 7E Modelinin Sekizinci Sınıf Öğrencilerinin Akademik Başarılarına Etkisi (Yayınlanmamış yüksek lisans tezi). Atatürk Üniversitesi, Erzurum.

Öztürk, M. (2014). 8. Sinıf kuvvet ve hareket ünitesine yönelik bilgisayar destekli ögretim uygulamalarının etkililiğinin araştırılması (Yayınlanmamış yüksek lisans tezi). Karadeniz Teknik Üniversitesi, Trabzon.

Öztürk, N. (2013). Altıncı sınıf fen ve teknoloji dersi ışık ve ses ünitesinde 5E ögrenme modeline dayalı etkinliklerin ögrenme ürünlerine etkisi (Yayınlanmamış doktora tezi). Gazi Üniversitesi, Ankara.

Pabuçcu, A. (2008). Improving 11th grade students' understanding of acid-base concepts by using 5E Learning Cycle Model. (Unpublished doctoral dissertation). Middle East Technical University, Ankara.

Parim, G. (2009). İlköğretim 8. sınıf ögrrencilerinde fotosentez, solunum kavramlarının öğrenilmesine, başarıya ve bilimsel süreç becerilerinin geliştirilmesinde araştırmaya dayalı öğrenmenin etkileri (Yayınlanmamış doktora tezi). Marmara Üniversitesi, İstanbul. 
Peşman, H. (2012). Method-approach interaction: The effects of Learning Cycle vs traditional and contextual vs non-contextual instruction on 11th grade students achievement in and attitudes towards physics (Unpublished doctoral dissertation). Middle East Technical University, Ankara.

Saraç, H. (2015). Çoklu ortam Destekli 7E Modeline Göre Tasarlanan Uygulamaların 5. Sinıf Fen Bilimleri Dersi “Maddenin Değişimi” "̈̈nitesinde Öğrencilerin Öğrenme Ürünlerine Etkisi (Yayınlanmamıs doktora tezi). Dumlupınar Üniversitesi, Kütahya.

Sarıkaya, S. (2007). Çevre Eğitiminde Interaktif Öğretim Yöntemleri (Yayınlanmamış yüksek lisans tezi). Celal Bayar Üniversitesi, Manisa.

Saygın, Ö. (2009). Ögrenme halkası modelinin lise ögrencilerinin nükleik asitler ve protein sentezi konularını anlamalarına, motivasyonlarına ve ögrenme stratejilerine etkisinin incelenmesi (Yayınlanmamış doktora tezi). Gazi Üniversitesi, Ankara.

Sertkahya, M. (2016). Gerçek Yaşamla Băglantılı Etkinliklerin Öğrencilerin Tutum ve Başarısına Etkisi: Enerji Ünitesi (Yayınlanmamış yüksek lisans tezi). Ege Üniversitesi, İzmir.

Sevinç, E. (2008). 5E ögrretim modelinin organik kimya laboratuvarl dersinde uygulanmasının ögrencilerin kavramsal anlamalarına, bilimsel süreç becerilerinin gelişimine ve organik kimya laboratuvarı dersine karsı tutumlarına etkisi (Yayınlanmamış yüksek lisans tezi). Gazi Üniversitesi, Ankara.

Sunar, S. (2013). The effect of context-based instruction integrated with Learning Cycle Model on students' achievement and retention related to states of matter subject (Unpublished doctoral dissertation). Middle East Technical University, Ankara.

Taşkoyan, S. N. (2008). Fen ve teknoloji öğretiminde sorgulayıcı öğrenme stratejilerinin öğrencilerin sorgulayıcı öğrenme becerileri, akademik başarıları ve tutumları üzerindeki etkisi (Yayınlanmamış doktora tezi). Dokuz Eylül Üniversitesi, İzmir.

Tekbıyı, A. (2010). Bağlam temelli yaklaşımla ortaöğretim 9. sınıf enerji ünitesine yönelik 5E modeline uygun ders materyallerinin geliştirilmesi (Yayınlanmamış doktora tezi). Karadeniz Teknik Üniversitesi, Trabzon.

Tiryaki, S. (2009). Yapılandırmacı Yaklaşıma Dayalı 5E Öğrenme Modeli ve İşbirlikli Öğrenme Yönteminin 8. Sınıf "Ses" Ünitesinin İşlenmesinde Başarıya ve Tutuma Etkisinin Araştırılması (Yayınlanmamış yüksek lisans tezi). Atatürk Üniversitesi, Erzurum.

Toprak, F. (2011). Fen Bilgisi Öğretmenliği Genel Kimya Laboratuvarında 3Eve 5EÖğretim Modellerinin Uygulanmasının Öğrencilerin Akademik Başarısı, Bilimsel Süreç Becerileri ve Derse Karşı Tutumlarına Etkisi (Yayınlanmamış yüksek lisans tezi). 19 May1s Üniversitesi, Samsun.

Toroslu, S. Ç. (2011). Effect of 7E learning model integrated with real-life context based instructions on students' conceptual achievement misconceptions and science skills about "energy" (Yayınlanmamış doktora tezi). Gazi Üniversitesi, Ankara.

Tortop, H. S. (2010). Yapılandırmacı yaklaşıma göre hazırlanan alan gezisi ile desteklenmiş proje tabanlı ögrenme modelinin güneş enerjisi ve kullanım alanları konusuna uygulanması (Yayınlanmamış doktora tezi). Süleyman Demirel Üniversitesi, Isparta.

Türker, H. H. (2009). Kuvvet Kavramına Yönelik 5E Öğrenme Döngüsü Modelinin Anlaml Öğrenmeye Etkisinin İncelenmesi (Yayınlanmamış yüksek lisans tezi). Niğde Üniversitesi, Niğde.

Ural Keleş, P. (2009). Kavramsal değişim metinleri, oyun ve drama ile zenginleştirilmiş 5 E modelinin etkililiğinin belirlenmesi: "Canlıları sınıflandıralım” örneği (Yayınlanmamış doktora tezi). Karadeniz Teknik Üniversitesi, Trabzon.

Uslu, S. (2011). İlköğretim II. kademede fen ve teknoloji ögrretiminde çalışma yapraklarının akademik başarı üzerine etkisinin incelenmesi (Yayınlanmamış doktora tezi). Adıyaman Üniversitesi, Adıyaman.

Uzun, B. (2010). Fen ve teknoloji ögretiminde kavramsal değişim stratejilerine dayalı olarak maddenin yapısı ve özellikleri konusunun ögretimi (Yayınlanmamış doktora tezi). Dokuz Eylül Üniversitesi, İzmir.

Ültay, N. (2012). Asit ve baz konusuyla ilgili REACT stratejisine ve 5E modeline göre etkinliklerin geliştirilmesi, uygulanmasl ve karşılaştırılması (Yayınlanmamış doktora tezi). Karadeniz Teknik Üniversitesi, Eğitim Bilimleri Enstitüsü, Trabzon.

Ünver, E. (2015). 5. Sinıf Öğrencilerinin Sindirim Sistemindeki Kavramları Öğrenmede Hikayelendirme Tekniğinin Etkisi (Yayınlanmamış yüksek lisans tezi). Ege Üniversitesi, İzmir.

Yalçın, F. A. (2010). 5E Öğrenme yönteminin 8. sınıf öğrencilerinin yaşamımızdaki elektrik konusunu anlamalarına ve fene yönelik tutumlarına etkisi (Yayınlanmamış doktora tezi). Sakarya Üniversitesi, Sakarya.

Yenice, E. (2014). Yapılandırmacı yaklaşımın 7E ögrenme modelinin 8. sınıf Fen ve Teknoloji dersi" mitoz ve mayoz bölünme" konusunda öğrencilerin akademik başarllarına etkisinin incelenmesi (Yayınlanmamış yüksek lisans tezi). Kafkas Üniversitesi Kars.

Yıldız, E. (2008). 5E modelinin kullanıldı̆̆ kavramsal değişime dayalı ögretimde üst bilişin etkileri: 7. slnıf kuvvet ve hareket ünitesine yönelik bir uygulama (Yayınlanmamış doktora tezi). Dokuz Eylül Üniversitesi, İzmir.

Yurt, Y. (2012). 5E Modelinin İlköğretim 6.Sını Öğrencilerinin Fen ve Teknoloji Dersine İlişkin Akademik Basarı ve Tutumlarına Etkisi (Yayınlanmamış yüksek lisans tezi). Mehmet Akif Ersoy Üniversitesi, Burdur.

Yörük, Z. N. (2008). Kimya Ö̆gretiminde 5E Öğrenme Modeline Dayalı Fen, Teknoloji, Toplum ve Çevre (FTTÇ) Yaklaşımının Etkileri (Yayınlanmamış yüksek lisans tezi). Hacettepe Üniversitesi, Ankara.

Zengin, E. (2016). Ortaokul 8. Sinıflarda Hücre Bölünmeleri Konusunun Öğretiminde 5E Öğrenme Modelinin Öğrenci Başarısına Etkisi (Yayınlanmamış yüksek lisans tezi). Atatürk Üniversitesi, Erzurum.

Ziyafet, E. (2008). Fen ve Teknoloji Dersinde Periyodik Çizelgenin Öğretiminde 5E Modelinin Öğrenci Tutum ve Başarısına Etkisi (Yayınlanmamış yüksek lisans tezi). Gazi Üniversitesi, Ankara. 